\title{
The Anisian continental-marine transition in Sardinia (Italy): state of the art, new palynological data and regional chronostratigraphic correlation
}

\author{
L. Stori ${ }^{1}$ - J. B. Diez ${ }^{2}$ - M. Juncal ${ }^{2}$ - R. De la Horra ${ }^{3}$ - V. Borruel-Abadía ${ }^{4} \cdot$ J. Martín-Chivelet ${ }^{3,5}$ • J. F. Barrenechea ${ }^{5,6}$. \\ J. López-Gómez ${ }^{5} \cdot$ A. Ronchi ${ }^{1}$
}

Received: 3 October 2021 / Accepted: 22 December 2021 / Published online: 16 February 2022

(c) The Author(s) 2022

\begin{abstract}
The scarce evidence of paleontological records between the upper Permian and the Anisian (Middle Triassic) of Western Europe could reflect (1) large stratigraphic gaps in the continental successions and/or (2) the persistence of disturbed conditions after the Permian-Triassic Boundary extinction event and the succession of ecological crises that occurred during the Early Triassic. In this context, the study of palynological associations, integrated with the stratigraphical and sedimentological data, plays a key role in dating and correlating the successions of the Western European domain and improves our understanding of environmental and paleoclimatic conditions. In some cases, pre-Anisian paleontological evidence is lacking, as in Sardinia (Italy), where a long gap encompasses the middle Permian (pars) to late Lower Triassic successions. Although fragmented and disseminated, the continental Lower-Middle Triassic sedimentary successions (Buntsandstein) of Sardinia have proved crucial to our understanding of the evolution of the southern edge of the Paleo-Europe and the different timings of the Tethys transgression (Muschelkalk facies) in some of these areas. Various paleogeographic reconstructions were attempted in previous works, without providing any consensus on the precise position of Sardinia and its surrounding seaways in the Western Tethys domain during this time interval. At present, the configuration and distribution of the subsiding and emerging landmasses and the temporal development of the transgressions of the Western Tethys during the Middle Triassic remain unclear. This work focuses on the stratigraphical, sedimentological and palynological aspects of three Middle Triassic continental-marine sedimentary successions in Sardinia, with particular attention to the analysis of the palynological associations sampled there, and it also provides a detailed review of all previous palynological publications on the Sardinian Anisian. The studied successions are: Su Passu Malu section (Campumari, SW Sardinia), Arcu is Fronestas section and Escalaplano section (Escalaplano, Central Sardinia). These sections were also correlated to other significant sections in the SW (Scivu Is Arenas) and NW (Nurra) parts of the island.
\end{abstract}

Keywords Palaeogeography $\cdot$ Palynology $\cdot$ Triassic $\cdot$ Buntsandstein $\cdot$ Biostratigraphy $\cdot$ Muschelkalk

\section{Resumen}

El escaso contenido paleontológico en el registro sedimentario entre el Pérmico superior y el Anisiense (Triásico Medio) del oeste de Europa estaría relacionado con 1) una prolongada ausencia de registro continental y/o 2) la persistencia de

L. Stori

lorenzo.stori01@universitadipavia.it

1 Dipartimento di Scienze Della Terra e Dell'Ambiente, University of Pavia, Pavia, Italy

2 Departamento de Xeociencias Mariñas e Ordenación do Territorio, Universidade de Vigo, 36200 Vigo, Spain
4 Departamento de Geología, Facultad de Ciencias, Universidad de Salamanca, Salamanca, Spain

5 Instituto de Geociencias, IGEO (UCM, CSIC), Madrid, Spain

6 Departamento de Mineralogía Y Petrología, Facultad de Geología, Universidad Complutense de Madrid, Madrid, Spain

3 Departamento de Geodinámica, Estratigrafía y Paleontología, Facultad de Geología, Universidad Complutense de Madrid, Madrid, Spain 
condiciones ambientales alteradas tras la crisis de la extinción del límite Pérmico-Triásico (PTB) y posteriores crisis asociadas durante todo el Triásico Inferior. En este contexto, el estudio detallado de asociaciones palinológicas integrado con datos estratigráficos y sedimentológicos juega un papel destacado para datar y correlacionar las sucesiones del registro sedimentario de esta edad en el dominio occidental de Europa, así como para conocer mejor los ambientes deposicionales y la evolución climática. En algunos casos no hay datos paleontológicos del Triásico previos al Anisiense, como es el caso de Cerdeña (Italia), donde la ausencia de registro sedimentario incluye desde parte del Pérmico medio hasta el Triásico Inferior. Aunque los afloramientos del Triásico Inferior y Medio (en facies Buntsandstein) de Cerdeña son incompletos y están separados entre sí, sin embargo, han mostrado proporcionado una información crucial para comprender la evolución del eje meridional de Paleo-Europa, así como para precisar las diferentes etapas transgresivas (en facies Muschelkalk) en estas áreas del Tethys occidental. Se han publicado diferentes trabajos intentando reconstruir el escenario paleogeográfico de Cerdeña y de sus diferentes corredores internos durante el intervalo de tiempo señalado, aunque no se ha alcanzado ningún consenso en cuanto a su posición ni en la configuración de zonas elevadas y deprimidas durante el citado intervalo de tiempo. El presente trabajo se centra en el estudio detallado de la estratigrafía, sedimentología y asociaciones de polen en tres secciones con una evolución de ambientes que incluyen desde el continental hasta el marino. Se hace un especial hincapié en el estudio de las asociaciones palinológicas muestreadas en este trabajo, así como en la revisión de otras asociaciones de edad Anisiense estudiadas por otros autores. Las secciones estudiadas aquí son: Su Passu Malu (Campumari, SO Cerdeña), Arcu is Fronestas and Escalaplano (Escalaplano, Cerdeña Central). Estas secciones han sido también correlacionadas con otras conocidas de distintas áreas de la isla, como Scivu is Arenas y Nurra, al SO and NO de Cerdeña, respectivamente.

Palabras clave Anisiense $\cdot$ Palinología $\cdot$ Cerdeña $\cdot$ Buntsandstein $\cdot$ Bioestratigrafía $\cdot$ Muschelkalk

\section{Introduction}

The late Palaeozoic era witnessed the formation of the Pangaea supercontinent, derived from the collision of Gondwana, Laurussia and several other microplates between the Carboniferous and the early Permian (e.g. Stampfli \& Borel, 2002; Stampfli et al., 2013; Pastor Galán et al., 2015). The Panthalassa ocean surrounded Pangaea while, to the east, the Tethys Sea occupied a triangular gulf that included the tropics during most of the Mesozoic. Immediately after the formation of Pangaea, during the early-middle Permian, the compressive geodynamic regime which led to the Variscan orogenic cycle progressively gave way to a large-scale transtensional-extensional regime which favoured the beginning of the break-up of the supercontinent, the subduction of the Palaeotethys oceanic ridge beneath Eurasia (Stampfli \& Borel, 2002; Stampfli et al., 2013), and the opening and westward expansion of the Neotethyan Ocean (e.g., Angiolini et al., 2013). The dismantling of the Variscan orogenic system and the widespread evolution of the late Palaeozoic rifting phases produced several small basins filled with terrestrial sediments, and the deposition of these sequences occurred in seasonal to semi-arid conditions: the continentalization of the climate after Pangaea led to pronounced warming and aridification throughout the late Permian (Wignall, 2007), which persisted into the Early Triassic. This latter period was characterized by severe hothouse conditions (e.g., Bourquin et al., 2011) and high temperatures (Payne et al., 2007; Sun et al., 2012), which underwent great fluctuations, also influenced by strong and enduring volcanic activity in the Siberian Traps Large Igneous Province
(Svensen et al., 2009), thereby contributing to a perturbation of the carbon cycle through the massive injection of $\mathrm{CO}_{2}$ into the atmosphere, causing ocean acidification and anoxia. The persistence of volatile environmental conditions and the significant instability of the ecosystem throughout the Early Triassic delayed the biotic recovery after the major P-T boundary extinction event (Wignall, 2007).

Our study focuses on Sardinia, Italy, a key location for understanding the Lower-Middle Triassic sedimentary record of the Western Tethys domain. The Triassic of Sardinia is characterized by the classic Germanic threefold lithologic sub-division: Buntsandstein, Muschelkalk and Keuper, which were sometimes incorrectly used as chronostratigraphic units. Sparse clastic terrestrial to transitional Early-Middle Triassic (Buntsandstein) deposits crop out in various parts of Sardinia (Costamagna \& Barca, 2002).

The first post-Palaeozoic marine transgression took place during the Middle Triassic and flooded the folded, metamorphosed and smoothed Variscan basement (Sinisi et al., 2014) in the southwestern, northwestern and central-eastern part of the island. This first transgressive pulse was represented by the transitional deposits of the upper Buntsandstein facies, or Röt facies, developed on alluvial fine-to-coarse grained deposits, eroded from the Variscan basement (i.e., Cala Viola, NW Sardinia, Fig. 1A; Monte Maiore and Escalaplano in Central-SE Sardinia, Fig. 1B; Scivu Is Arenas (Arburese) and Campumari in SW Sardinia, Fig. 1C, D). After these transitional deposits, a succession of dolomites, limestones and marls, or Muschelkalk facies, represents the first complete incursion of the Tethys Sea into Sardinia (e.g., Bourquin et al., 2011). 


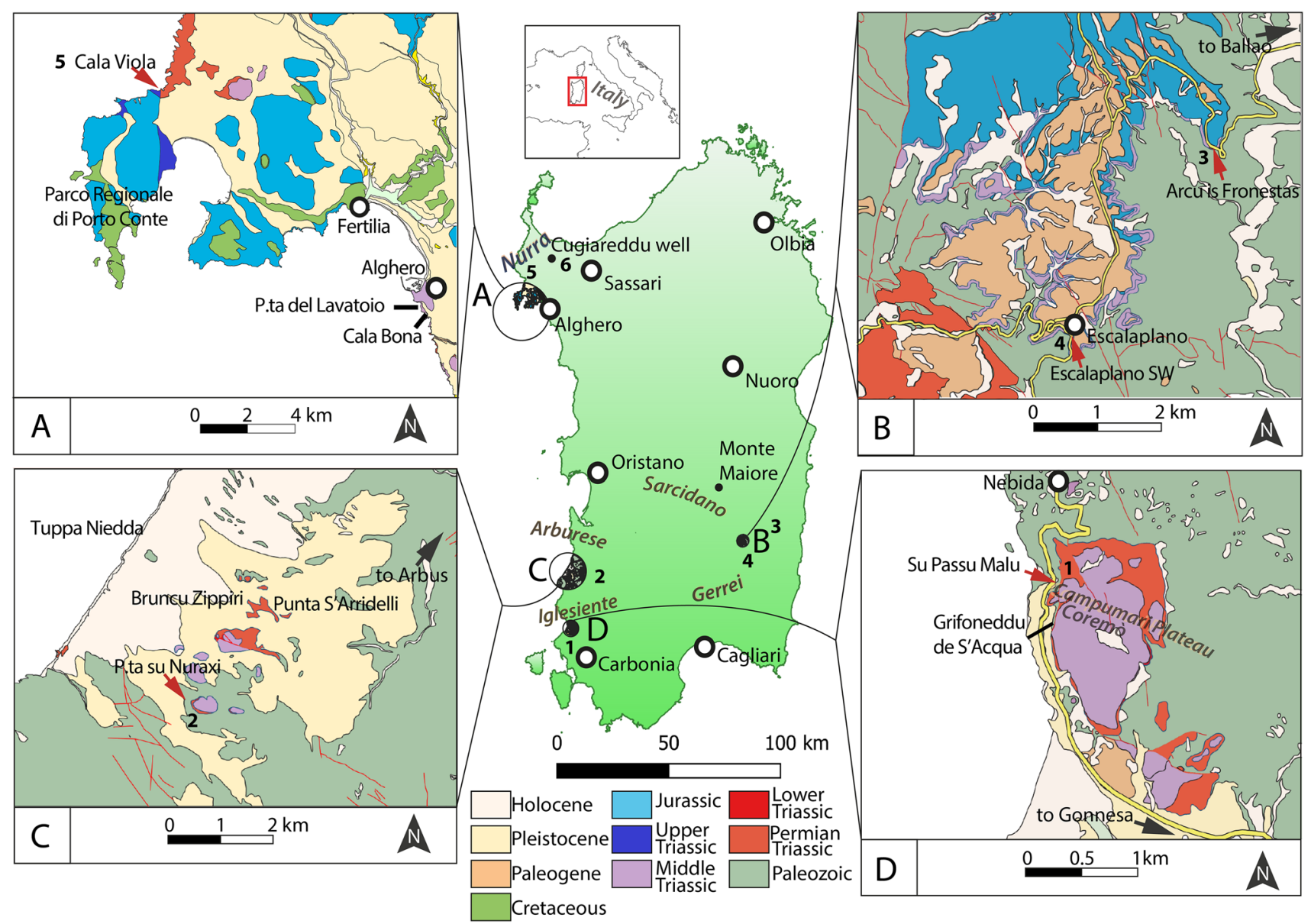

Fig. 1 Location and geological sketch maps of the Middle Triassic sequences of Sardinia discussed in the text. A Cala Viola and Alghero (Nurra); B Escalaplano (Sarcidano); C Scivu-Is Arenas (Arburese); D Campumari (Iglesiente)

More particularly, central Sardinia is considered a structural highpoint during the Anisian that was progressively submerged until the maximum eustatic flooding during the Ladinian (Costamagna \& Barca, 2002, 2016). The palynological characterization of these Middle Triassic deposits in this area and other parts of Sardinia has permitted some authors to propose correlations with the Alpine standard stages and substages (Pittau Demelia \& Del Rio, 1980; Frechengues et al., 1983; Pittau Demelia \& Flaviani, 1982a, 1982b, 1983; Barca et al., 1985; Pittau \& Del Rio, 2002). However, despite the good characterization and correlation with the adjacent domains, a more detailed study of these successions could enhance our understanding of processes that still remain unclear, such as the detailed configuration and distribution of the subsiding and emerging landmasses and the temporal development of the transgressions of the Western Tethys during the Middle Triassic. New stratigraphic analyses and palynological samplings were made in the Escalaplano area (Central Sardinia, Fig. 1B) and Campumari (SW Sardinia, Fig. 1D) to accurately define the age of such sediments and, thus, the beginning of Triassic deposition and the first marine incursion into this sector of the Western Peri-Tethys realm. Together with these new samplings in the cited areas, the known Anisian palynological associations of Escalaplano, Campumari, Scivu Is Arenas (Arburese) and Nurra were considered to obtain a regional correlation for the Middle Triassic continental-to-transitional deposits in the island.

This work also provides up-to-date stratigraphical and sedimentological analyses, which particularly further our knowledge of the palynostratigraphical zonation of these successions and permit a more accurate determination of the age of such sediments and the beginning of both continental and marine Triassic deposition in this sector of the Western Peri-Tethys domain.

\section{Geological setting}

In Sardinia, the post-Variscan deposits are arranged in three main sedimentary sequences: the first (lower Permian) is related to the development of the aforementioned 
intra-Pangaea lateral mega shear system; the second (lower Permian to early middle Permian) is related to a more mature post-orogenic rifting phase; and the third (Early-Middle Triassic) is associated with fluvial sedimentation in medium-sized basins and the first eastward marine incursions through narrow corridors (Cassinis et al., 2003). This third sedimentary sequence led to the deposition of red continental terrigenous sequences in Buntsandstein facies, represented by the Punta S'Arridelli Formation and the Riu Is Corras Formation (SW Sardinia Fig. 2: 1,2), the Escalaplano Formation in the Sarcidano area (Central Sardinia Fig. 2: 3, 4) and the Conglomerato del Porticciolo and Arenarie di Cala Viola Formation in the Nurra region (NW Sardinia Fig. 2: 5, 6). According to Costamagna and Barca (2002), these units were mainly formed in a small ephemeral distal fan environment, as the development of a significant fan-delta complex could have been hindered by the low landforms resulting from the several post-Variscan erosion cycles, which severely reduced most of the reliefs through intense chemical and mechanical weathering processes (Scotese \& Schettino, 2017). The passage from the Buntsandstein to the shallow marine, carbonate platform environment in Muschelkalk facies is marked by the presence of transitional deposits in Germanic-like "Röt" facies, which present different lithologies from, for instance, those defined in Iberia. The first accurate and illustrated documentation of the Sardinian "Röt" facies can be found in Costamagna, (2011, 2012); it is characterized by marls and evaporitic lithologies which can be seen, for example, in the Punta S'Arridelli Formation and at the uppermost levels of the Riu Is Corras Fm (Fig. 2). These fms. also show a prominent carbonate influence, the genesis is still subject to debate; it is difficult to interpret due to the occurrence of pedogenetic processes, as testified by the presence of caliches (Barca et al., 1995b; Cocozza \& Gandin, 1976). As regards the $\mathrm{NE}$ and SE successions, the transition to the marine environment is quite abrupt, with only a few meters of marls

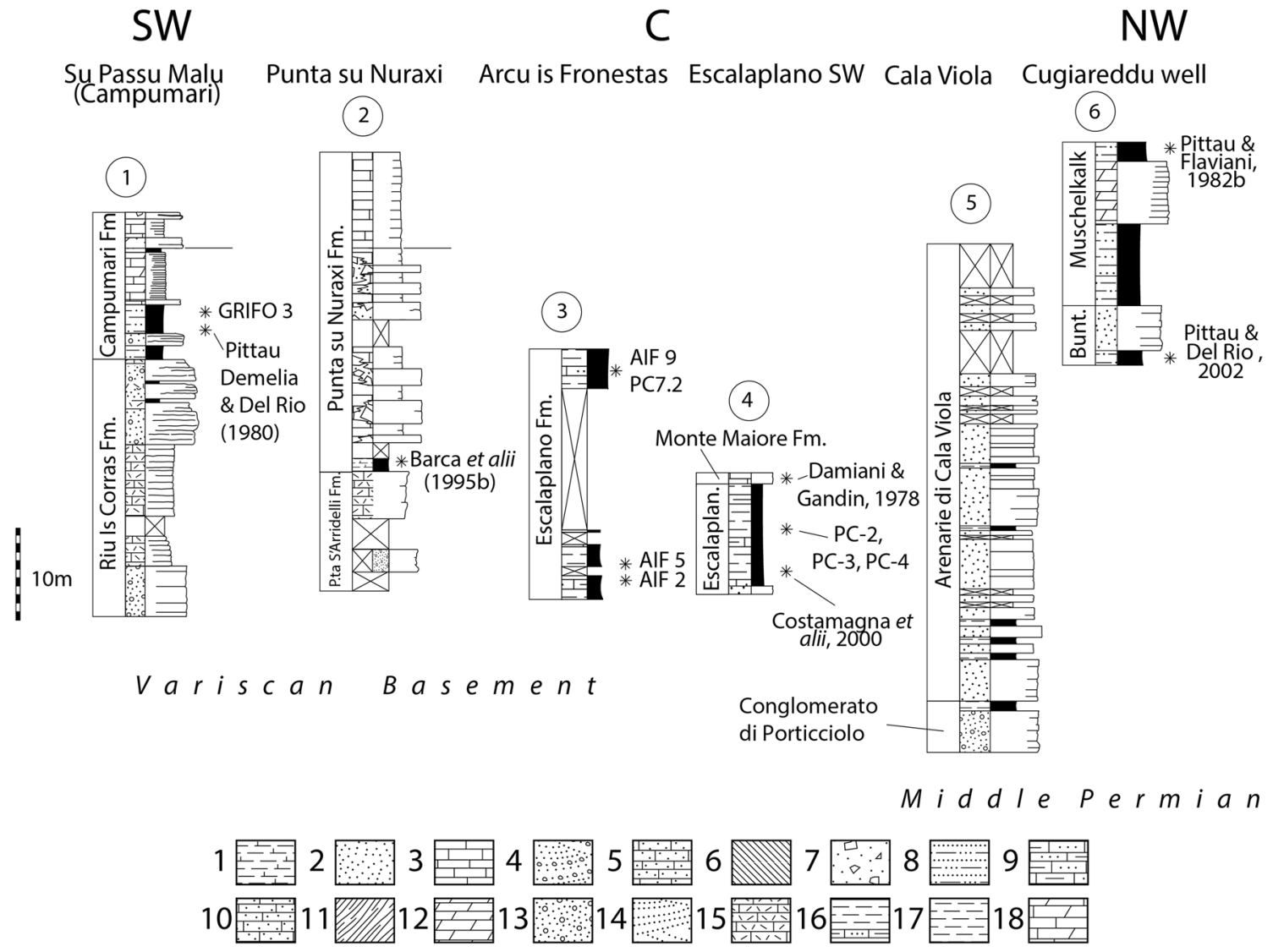

Fig. 2 Simplified sections, from SW to NW, with * indicating the pollen samples dating the successions. (1) Su Passu Malu (Campumari, Iglesiente) (2) Punta su Nuraxi (Scivu is Arenas, Arburese) (3) Arcu is Fronestas (Escalaplano) (4) Escalaplano SW (Escalaplano) (5) Cala Viola (Nurra) (6) Cugiareddu well (Nurra). (1) Marls (2) Sandstones (3) Limestones (4) Crossbedded conglomerates, (5)
Sandy limestones (6) Gypsum (7) Breccias (8) Bedded sandstones (9) Dolomitic limestones (10) Interbedded sandstones and siltstones (11) Schist (12) Dolostones (13) Conglomerates (14) Crossbedded sandstones (15) Calcretes (16) Interbedded shales and silty limestones (17) Clays (18) Silty limestones. See Fig. 1 for locations 
passing into the dolostones of the Muschelkalk, as in the Escalaplano Formation, where the influence of the marine environment is testified by the presence of the aforementioned "Röt" facies, consisting of calcareous-evaporitic intercalation containing wrinkled algal mats (Costamagna $\&$ Barca, 2002). The studied sections are included in four regions of the island: Escalaplano-Sarcidano/Gerrei region (Central-SE Sardinia), Campumari-Iglesiente region (SW Sardinia), Scivu Is Arenas-Arburese region (SW Sardinia) and Nurra region (NW Sardinia).

\subsection{Central-SE Sardinia (Sarcidano-Gerrei region)}

Close to the village of Escalaplano, to the SW (SarcidanoGerrei region, Fig. 1B), the post-Variscan deposition is mainly represented by a lower Permian volcano-sedimentary sequence that fills a small (about $15 \mathrm{~km}^{2}$ ) intramontane basin (Fig. 1B). On the whole, the extruded calc-alkaline magmatic products in this succession have an extrabasinal origin and largely exceed the strictly sedimentary units.

According to Pecorini (1974), Ronchi (1997) and Ronchi et al. (2008), the entire Permian succession can be subdivided into two main parts, namely "Lower" and "Upper" volcanic and sedimentary successions: both of these begin with a coarse sedimentary unit, continue with reworked volcaniclastites, tuffites, lacustrine-to-palustrine deposits and end with, respectively, an acidic ignimbrite deposit and an andesitic lava flow. Nine lithostratigraphic units have been distinguished within the two cited volcano-sedimentary portions by Ronchi et al. (2008), which seem to be separated by a paraconformity(?). The estimated average thickness is approximately $150 \mathrm{~m}$, possibly reaching a maximum of almost $200 \mathrm{~m}$ in the basin's northwestern sector.

Conversely, Buntsandstein deposits all around the Escalaplano area (Fig. 1B, 3) directly overlay the Variscan basement (Pertusati et al., 2000a, b) or, very locally, the Permian sediments. Dorn (1940) assigned the succession outcropping at Escalaplano to the Keuper (Late Triassic), due to the presence of gypsiferous shale. Later, other authors working on this section suggested a Middle Triassic age and referred to a transitional "Buntsandstein" laid down before the subsequent Muschelkalk marine carbonate transgression (Damiani \& Gandin, 1973a, 1973b, 1973c; Fazzini et al., 1974; Fontana et al., 1982; Pecorini, 1974). Subsequently, Pittau (Ronchi, 1997) studied in detail the palynological associations in the Middle Triassic succession of this area.

In the Sarcidano-Gerrei area (Central-Southeastern Sardinia), the Triassic deposits are continental-to-transitional (Escalaplano Formation; Costamagna et al., 2000) and shallow marine (Mt. Maiore Formation; Costamagna et al., 2000). These formations are unconformably covered, in their turn, by Middle Jurassic or Eocene alluvial formations (e.g.,
Ronchi, 1997; Costamagna \& Barca, 2016; Costamagna et al., 2007; Costamagna et al., 2016) (see the unconformable contacts in Escalaplano village SW, Is Forreddus and Arcu is Fronestas sections in Fig. 3). The reduced thickness of the Triassic sections in this area is due to long and intense Mesozoic and Cenozoic erosional phases.

\subsection{SW Sardinia: Campumari (Iglesiente region)}

The Campumari-Coremò area is located along the southwestern coast of Sardinia, in the Iglesiente area, and it consists of a series of small tabular reliefs with slightly different heights, forming a plateau with a maximum altitude of 219 m (Fig. 1D).

The post-Variscan "Permo-Triassic" auctt. deposits vary from a minimum of $10 \mathrm{~m}$ in the "Case Miniera Paneccani" locality up to a maximum of $45 \mathrm{~m}$ in the Su Grifoneddu de S'Acqua area, and they lie in angular unconformity over the low metamorphic basement (Fig. 2B 1).

The Campumari plateau has been studied since the end of the nineteenth century (Lovisato, 1881; Tornquist, 1902; Novarese, 1914; Taricco, 1928) but there has never been any agreement about the chronology of its sedimentary formations, which have been attributed to very different ages (Permian, Triassic, Cretaceous and Eocene). It was not until the work of Cocozza and Gandin (1976) that the sequence was studied in detail; these authors recognized a stratigraphic gap between the true Eocene deposits and the underlying carbonate lithologies, and these latter deposits were finally attributed to the Triassic, based on facies analogies with the Triassic sediments of the Scivu-Is Arenas and Monte Maiore areas. Later, Pittau Demelia \& Del Rio (1980) described a palynological association with a discontinuous gray-blackish clay level located in the upper part of the "B interval" (Cocozza \& Gandin, 1976), now formalized as "Su Passu Malu Member" (Barca \& Costamagna, 2003). They therefore attributed at least the upper part of the clastic unit of the Campumari succession to the Middle Triassic or "Lower Muschelkalk". Subsequently, Barca and Costamagna (2003) performed another detailed sedimentological study of the Campumari sequence, identifying and formalizing two formations and their respective members, the Riu Is Corras Formation and Campumari Formation (Costamagna $\&$ Barca, 1997b) (Fig. 2:1). The former consists mainly of conglomerates and calichified, brecciated horizons liying unconformably over the basement; it has been interpreted as the product of a coastal plain, with a distal fan environment in a semi-arid hot climate (Cocozza \& Gandin, 1976; Costamagna \& Barca, 2002). The overlying Campumari Formation is sub-divided into two members: the Su Passu Malu Member begins with dark marly-clay deposits (locally with thin carbonate intercalations) and mainly consists of thinly stratified, laminated, yellowish marly dolostones 


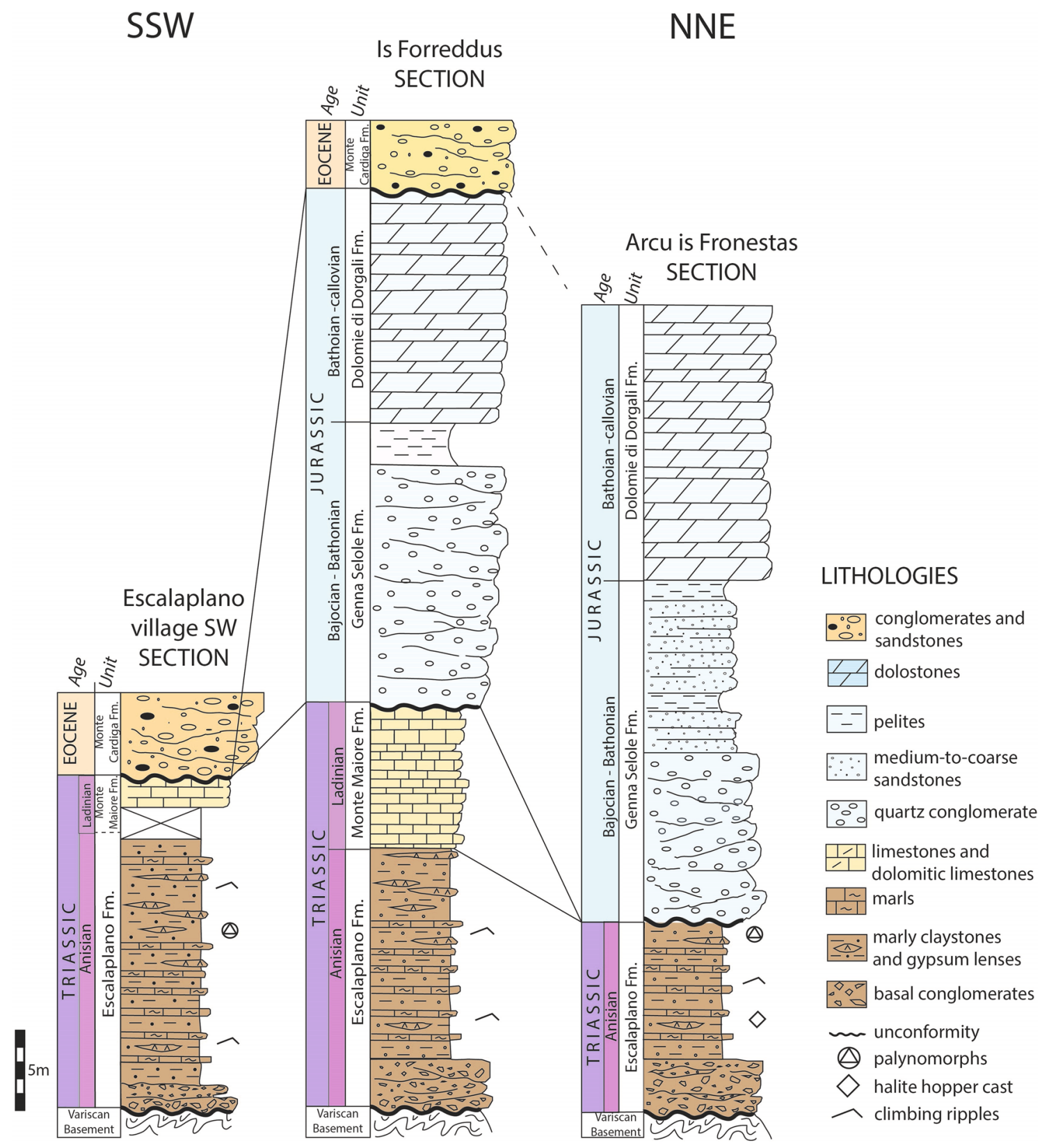

Fig. 3 Simplified sections to show the stratigraphic relationships and erosional surfaces in the Escalaplano area

bearing sulphate pseudomorphs and chert nodules, and the Grifoneddu de S'acqua Member, which is composed of dolostones and starts with a breccia horizon marking the passage to a shallow marine, restricted lagoonal environment (Costamagna \& Barca, 2002).

\subsection{SW Sardinia: Scivu Is Arenas (Arburese region)}

The Triassic of the Scivu-Is Arenas area overlies the Variscan metamorphic basement and is in turn covered by Quaternary deposits (calcarenites and aeolian sands), forming small reliefs (Figs. 1C, 4A). The area was first studied by Bornemann (1881), who attributed the outcrops to the Triassic sedimentary record on the basis of the fossil content (e.g., presence of Myophoria goldfussi Von Alberti, Gervilleia subglobosa Credner, Rhyzocorallium jeneense Zenker, among others) and correlated the succession to the Grès Bigarré of Provence, due to similarities in facies. It was only after more recent studies (Barca et al., 1995b; Costamagna \& Barca, 2002; Damiani \& Gandin, 1973b) that these deposits received more detailed chrono- and litho-stratigraphic subdivisions, as reported below. 
The older Triassic unit, namely Punta S'Arridelli Formation (Costamagna \& Barca, 2002), lies nonconformably on top of the Palaeozoic basement (Fig. 2: 2, 4A) and consists of two sub-units, the lower Su Ripostiggiu Member and the upper Bruncu Pilloni Member, representing the evolution from a continental braided stream environment, to a more transitional, sabkha-to-shallow marine setting (Costamagna \& Barca, 2002). The Su Ripostiggiu Member starts with thin reddish breccias continuing to coarse sandstones with angular-to-subrounded clasts coming from the eroded metamorphic basement and volcanic detritus, and it then evolves upwards to purple-reddish paleosols and calicified carbonate layers containing fragments of basement and reddish sandstone (Fig. 4C). From the base to the top of this member, there is a decrease in the clast size and a variation in clast composition, which changes from almost totally volcanic to exclusively metamorphic basement fragments, marking an increase in erosive sub-aerial conditions (Barca et al., 1995a, 1995b). The Su Ripostiggiu Member (about 20 m) passes upwards (or laterally to the south) to the Bruncu Pilloni Member, formed by dedolomitized, locally cavernous limestone, bearing siliceous pseudomorphs, levels of dissolution-collapse breccias and traces of calicitization processes in its upper part.

The Punta Su Nuraxi Formation (Costamagna \& Barca, 2002) overlies Punta S'Arridelli Formation with a slight angular unconformity (Fig. 4A) and is divided into two different sub-units: a lower Case Pisano Member and an upper Bruncu Zippiri Member (Costamagna \& Barca, 2002). The Case Pisano Member starts locally with a dark, marly mudstone layer, yielding a microflora assemblage suggesting an upper Anisian age, according to Barca et al. (1995b).

There follow metric alternations of massive, cavernous, calcareous mudstones bearing siliceous pseudomorphs and evaporitic minerals, and whitish layered and cross-laminated calcarenites-calcilutites. Salt tectonic structures (folds several metres in size) occur in this sub-unit, along with collapse-dissolution breccias and localized calcrete structures. The Case Pisano Member evolves upwards in the Bruncu Zippiri Member through a thick layer of dissolution-collapse breccias. The Bruncu Zippiri Member consists of two facies, the first being represented by blue-gray limestone with reddish intercalation of bioclastic grainstones-packstones, locally presenting cross, wavy and planar lamination, fossil content (bivalves, foraminifera and algae) and rare evidence of storm beds eroding the substratum (Costamagna \& Barca, 2002). The second facies is represented by massive calcarenite-calcilutite (packstones to wackestones) evolving upwards into gray-reddish (Fig. 4E), marly limestones (wackestones to mudstones), showing bioturbation structures classified as Planolites and Paleophycus tubularis (Costamagna \& Barca, 2002; Moore, 1962).

\subsection{NW Sardinia (Nurra region)}

The post-Variscan succession of the Nurra region (Northwestern Sardinia, Fig. 1A) was deposited on the Variscan crystalline basement during the early Permian to Middle Triassic time-span; it is represented by a thick pile of continental sediments (about $700 \mathrm{~m}$ thick), mainly Permian, evolving into continental-to-shallow marine Triassic deposits with the classic Germanic facies (Buntsandstein, Muschelkalk and Keuper Auct.) (Fig. 4B). The first and second sequence belong to the Permian and are represented by the stacking of different fluvial to lacustrine formations (e.g., Cassinis et al., 2003; Costamagna, 2019).

The third sequence (approx. $50 \mathrm{~m}$ thick) consists of two formations, namely the Conglomerato del Porticciolo and Arenarie di Cala Viola (Fig. 2: 5), separated by a minor erosional surface. The former (up to $12 \mathrm{~m}$ thick) was accumulated in a gravelly braided river setting under conditions of persistent aridity, as suggested by the common occurrence of wind-worn clasts (Cassinis et al., 2003; Durand, 2008). Its base consists of the alternation between massive to cross-bedded ortho- and para-conglomerates (mainly polycrystalline quartz), presenting imbrication features and cross-laminated siltstones to sandstones. The top of the formation consists of a 4-5 m alternation of trough cross-bedded, medium-fine sandstones of fluvial and aeolian origin and coarser pebbly sandstones.

The Arenarie di Cala Viola Formation is about $40 \mathrm{~m}$ thick and unconformably overlies the Conglomerato del Porticciolo Formation. Its base is mainly represented by dark continental red sandstones and siltstones arranged in thin beds that present small, pedogenic-origin, intraformational breccias, sets of climbing ripples evolving into horizontal to low-angle laminated or trough cross-bedding, with subordinate mudstones in the lower part. It is overlain by a few meters of gray-green, pink and reddish, medium- to coarse-grained sandstones, with the presence of lensoid geometries and trough cross-bedding (Fig. 4D). Further up, in the middle-upper part of the unit, there are thinly bedded to well-bedded, medium- to fine-grained, dark orange/red to purple sandstones and siltstones, while, finally, the top of the unit consists mainly of whitish-green to gray siltstones and claystones. The Arenarie di Cala Viola Formation marks a dramatic change in sedimentary and climatic conditions. In fact, while the Conglomerato di Porticciolo was probably deposited during the late Early Triassic (late Olenekian) sedimentary cycle, under arid to hyper-arid conditions (Durand, 2006, 2008; Bourquin et al., 2007, 2011; Borruel-Abadía et al., 2019), similarly to the Poudingue de Port-issol in Provence, the Arenarie di Cala Viola Formation with its finer grained facies, was deposited in a terminal fan setting under semi-arid conditions (Cassinis et al., 2003; Citton et al., 2020; Durand, 

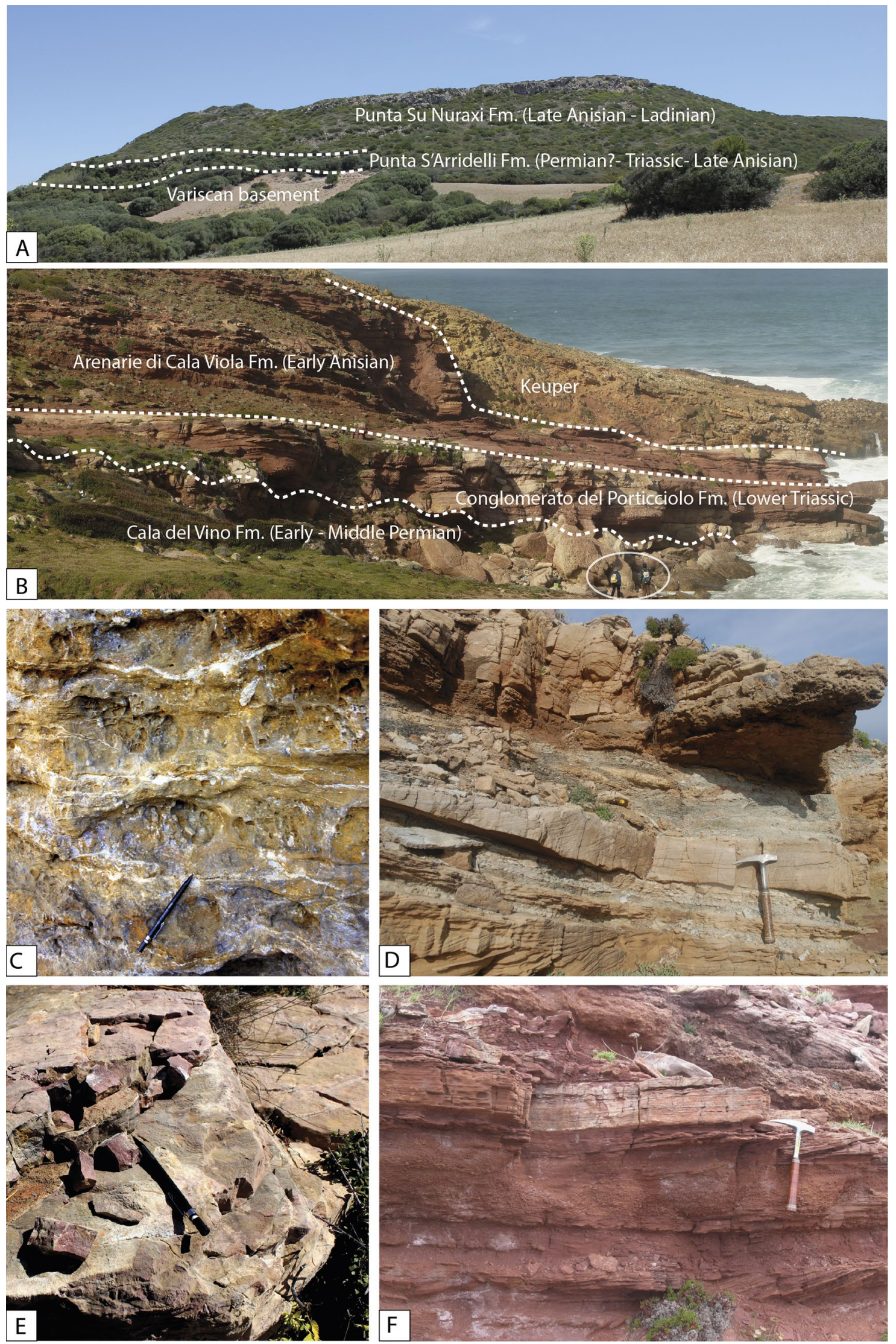
४Fig. 4 Field pictures from Scivu-Is Arenas and Cala Viola. (A) panoramic view of the Punta Su Nuraxi hill from SE; (B) panoramic view of the Cala Viola section with Lower Triassic Porticciolo unconformably overlying middle Permian Cala del Vino Formation, overlied by Middle Triassic Arenarie di Cala Viola Fm.; (C) caliches from the Punta S'Arridelli Formation; (D) yellowish trough crossbedded sandstone bodies and gray-greenish siltitic laminated layers from Arenarie di Cala Viola Formation; (E) gray-reddish limestones of the Punta su Nuraxi Formation; (F) inundation sequences from Arenarie di Cala Viola Formation

2006, 2008), as testified by the presence of pedogenetic carbonate concretions, mud cracks, tree-related bio-sedimentary structures and the presence of inundite sequences (Fig. 4F) (sensu Seilacher, 1982). Some authors (i.e. Costamagna, 2012; Fontana et al., 2001) have postulated a tidal influence in the Arenarie di Cala Viola Formation, based on the sedimentology and stratigraphic position of this unit, which narrowly predates the widespread Middle Triassic marine transgression documented by the 'Muschelkalk'-type carbonates.

\section{Material and methods}

\subsection{Stratigraphy}

For this work, detailed bibliographical research was undertaken, in order to review and update the stratigraphical and sedimentological data related to the areas of interest. The sections mentioned below were re-examined and studied, with particular attention to sedimentary facies recognition and associations. They crop out in the Iglesiente (SW Sardinia) and the Sarcidano-Gerrei (Central-SE Sardinia) regions of the island (Fig. 1).

In the former area, more specifically on the Campumari plateau, the Su Passu Malu section was analyzed. In the latter area, two sections were described: the first cropping out at the southern entrance of the Escalaplano village, and the second a few $\mathrm{km}$ to the north, in the Arcu is Fronestas locality (Fig. 1B). The stratigraphy and facies analyses provided by the fieldwork were integrated into the pre-existing information and complemented by new palynological data and revised older data. Based on the new interpretation of the microfloristic associations, correlations were drawn at a regional level. In a broader interregional context, the data have been used to better frame Sardinia in the palaeogeographic evolution of the Western Tethys during the Anisian.

\subsection{Palynology}

\subsubsection{Methodology for palynological revision}

A precise review of all the previous palynological publications on the Sardinian Anisian was undertaken for the present work, and it was necessary to establish the validity of these data for our purposes.

The minimum conditions for considering the data valid were:

1) correct figuration: lists of taxa without representation were not considered valid since there was no possibility of confirming or identifying the palynomorph.

2) correct location: each palynomorph association must be referred to an exact position in the stratigraphic section in which it was sampled.

Based on these premises, identifications from previous papers that meet these requirements could be incorporated into the discussion, together with unpublished data (Diez, 2000) and new data obtained in the last field trips undertaken by the authors of the present paper.

\subsubsection{Palynological analyses}

This paper presents unpublished and revised results from Diez's PhD thesis (2000) collected in 1996 in the Escalaplano area: three samples (PC-2, PC-3 and PC-4) at the southern entrance to Escalaplano village (Escalaplano SW section, Fig. 5) and another sample (PC-7.2) taken from the Arcu is Fronestas section, north of the same village (Fig. 6). Three new samples (AIF-2, AIF-5, and AIF-9) were later collected in 2015 and 2016 fieldwork in the Arcu Is Fronestas section and another one (GRIFO 3) was collected from the Su Passu Malu section on the Campumari site (Campumari section, Fig. 7).

Palynological samples were processed using $\mathrm{HCl}-\mathrm{HF}-$ $\mathrm{HCl}$ classic attack techniques, as described by WOOD et al. (1996), in the Palynology Laboratory in the Department of Geosciences at the University of Vigo (AIF-2, AIF-5, AIF-9, GRIFO 3) and the Paleobotany Laboratory in the University Pierre et Marie Curie, Paris-6 (PC-2. PC-3, PC-4 and PC-7.2). A dispersing agent was added to facilitate filtering and sieving at $10 \mu \mathrm{m}$. The palynological slides were studied under a Leica DM2000 LED, and the photomicrographs were taken with a Leica ICC50 W camera using $\times 1000$ magnification. 


\section{Escalaplano SW}

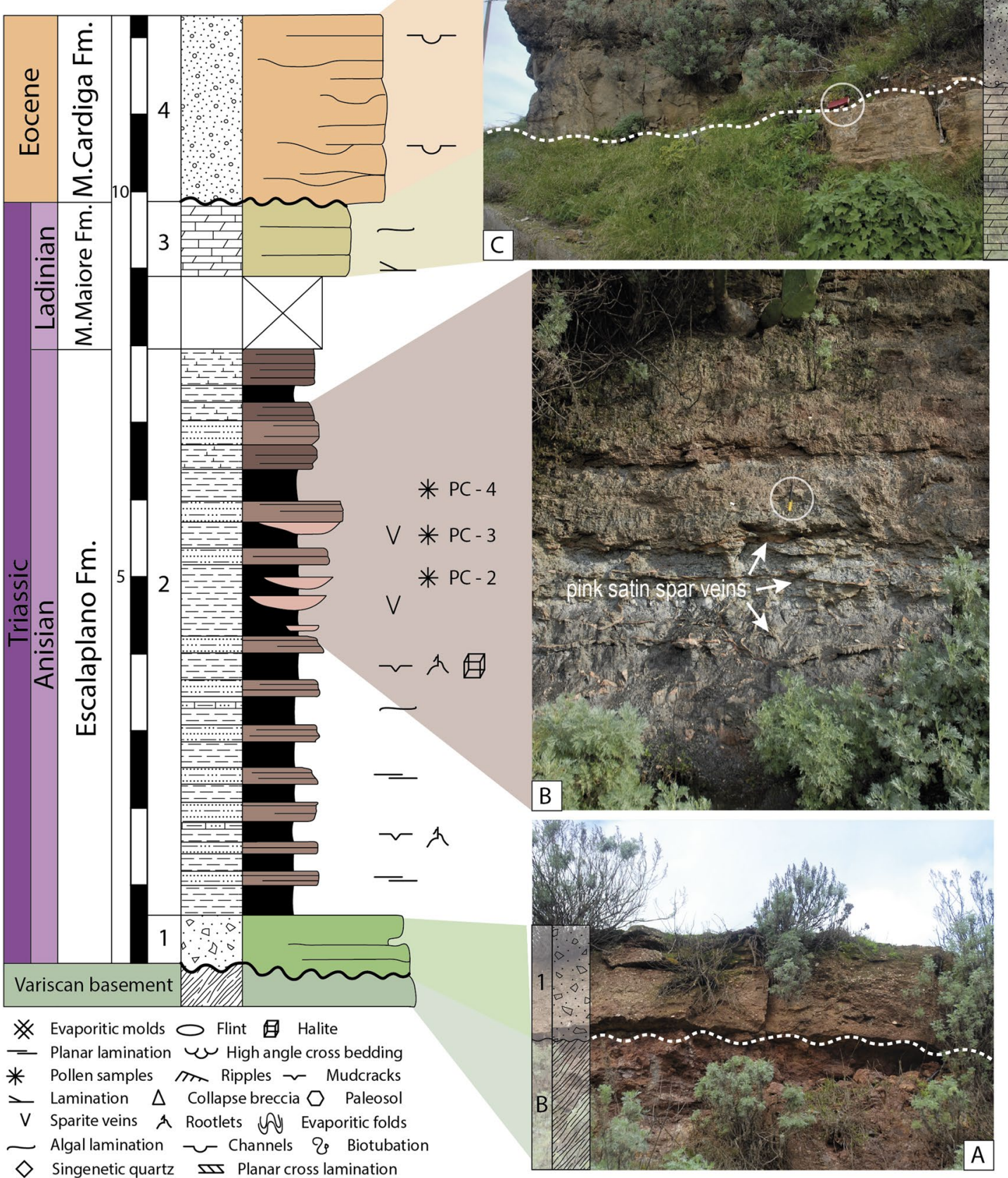

Fig. 5 Stratigraphic section of the outcrop located at the Escalaplano SW entrance. (A) Basal reddish conglomerates lying over the Variscan basement; (B) Anisian satin spar-bearing marly argillites with pollen sample site (asterisk) (pen for scale); (C) contact between the Muschelkalk and the Eocene conglomerates (booklet for scale). See also Fig. 2 to complete the legend 


\section{Arcu Is Fronestas}

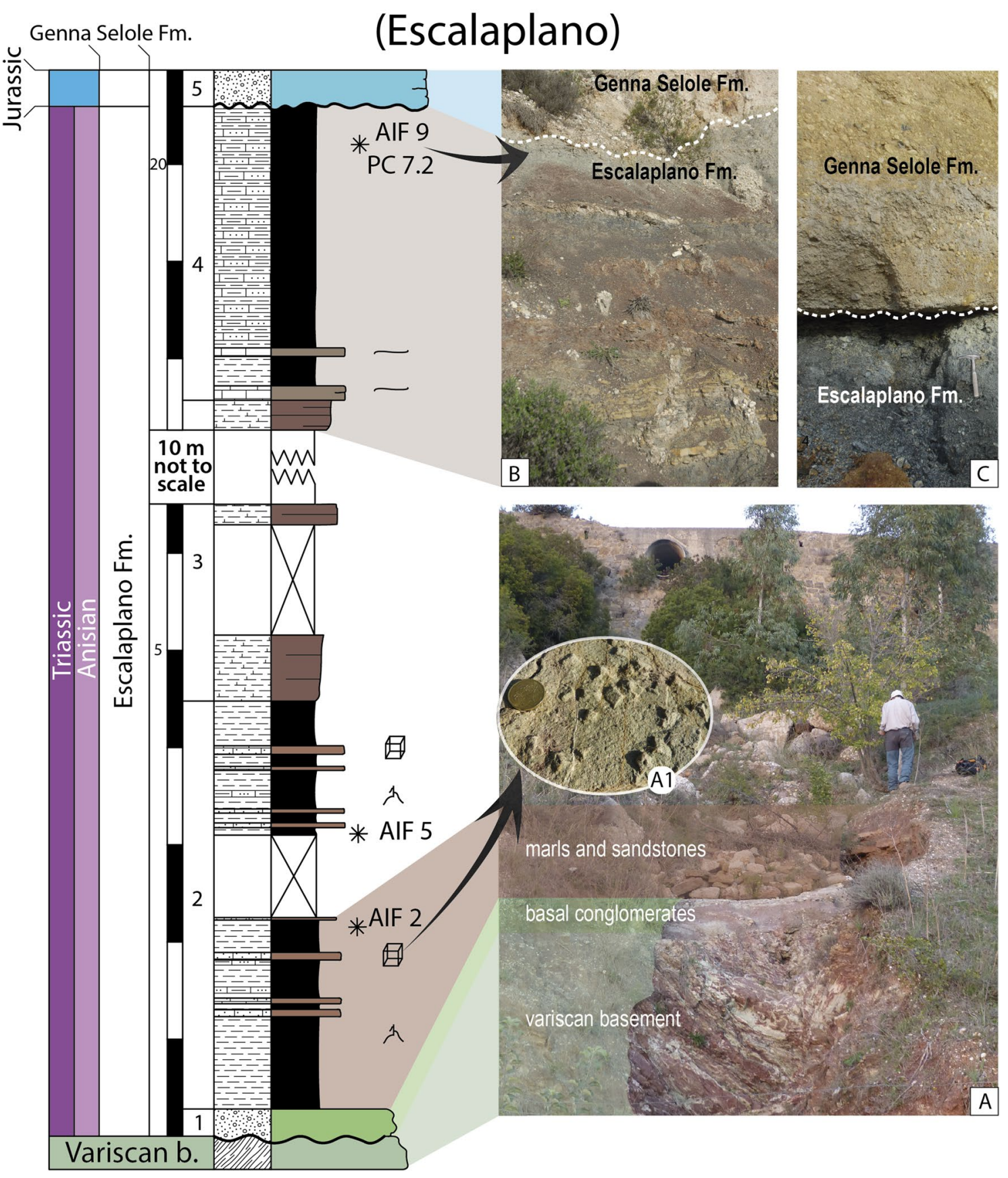

Fig. 6 Arcu Is Fronestas section. (A) basal reddish conglomerate lying over the Variscan basement's schists; (A1) halite casts; (B) dark gray claystones and marly sandstones $(\mathbf{C})$ black claystones to yellowish marly claystones; see also Figs. 2 and 4 to complete the legend 


\section{Su Passu Malu (Campumari, SW Sardinia)}

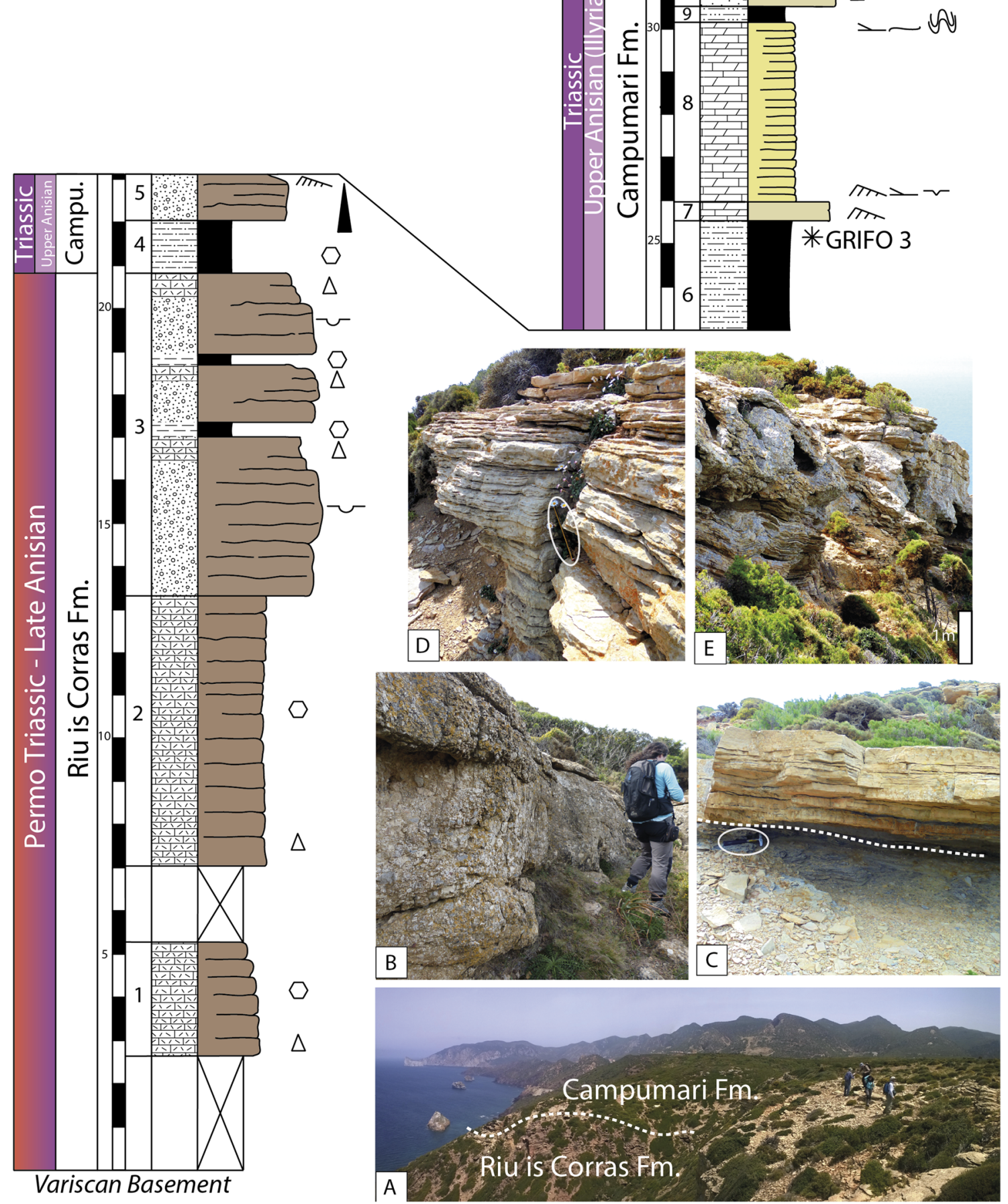

Fig. 7 Campumari section. (A) Panoramic view of the CampumariCoremò plateau; (B) conglomerates of the Riu Is Corras Formation; (C) detail of the dark gray mudstones overlaid by the yellow, lami- nated dolostones; (D) detail of the yellow, laminated dolostones; $(\mathbf{E})$ alternation of breccias and dolostones from the upper part of the Grifoneddu Member. See also Figs. 2 and 4 to complete the legend 
The slides are stored in the Palynology Laboratory in the Department of Geosciences at the University of Vigo.

\section{Results}

\subsection{Stratigraphic sections}

\subsubsection{Escalaplano}

Reddish clastic sediments with chalky and marly-clayey intercalations, up to about $20 \mathrm{~m}$ in thickness, unconformably overlie the Variscan metamorphic basement at the northeastern margin of the Permian Escalaplano basin (Fig. 1). The marked unconformity between the crystalline basement and these Middle Triassic siliciclastics can be observed along the SS 128 Ballao-Escalaplano road, just before the first buildings at the southern entrance to the village of Escalaplano (Fig. 1B). A stratigraphic superimposition of the Triassic deposits on the Permian succession has been described so far (Ronchi, 1997) only in the Arcu 'e Azzinuri locality (i.e., along the Escalaplano-Orroli road, just a few hundred metres west of the village).

Some representative stratigraphic sections have been described in the Triassic sedimentary deposits in the Escalaplano area (Fig. 1). Two of these are described herein, with indications of the palynomorph horizons. At Escalaplano's southern entrance (SW Escalaplano section, Fig. 5), the depositional environment evolves from continental alluvial environment (Buntsandstein) to transitional salted lagoons, forecasting the marine (Muschelkalk) transgression (Costamagna et al., 2000). The following lithostratigraphic units can be recognized, from their base lying on violet schists from the basement to the Eocene siliciclastics:

-reddish basal polygenic conglomerates and breccias (Fig. 5A), with angular elements of the underlying metamorphic basement, quartz pebbles and Permian volcanic rocks, embedded into a sandy matrix alternating with reddish sandstones $(0-2 \mathrm{~m})$. This unit is very reduced northwestwards, in the area where the unconformable contact with the basement is underlined by fine-grained deposits;

-dark red to violet to gray-green, evenly bedded in $\mathrm{cm}$-dm thick layers, mica-rich siltstones, sandstones, marly claystones and marls. Irregular white-to-pink satin spar veins occur frequently $(0-10 \mathrm{~m})$ (Fig. $5 \mathrm{~B})$. This lithofacies can reach up to $15 \mathrm{~m}$ in the area; in the upper part, there are alternating beds of dark claystones, thin dolomitic marls, siltstones and $\mathrm{cm}$-irregular layers of pink and white satin spar;

- yellowish light brown to gray irregularly bedded limestones and dolomitic limestones (Mushelkalk Auctt.) (3 m) (Fig. 5C). These carbonates, which can reach about $20 \mathrm{~m}$ in the area, are unconformably overlain by alluvial coarse
Eocene deposits in this locality. To the north of the village of Escalaplano (i.e., Is Forreddu and Arcu is Fronestas sections), the same Middle Triassic siliciclastics are in turn directly overlain by Middle Jurassic quartz conglomerates (Genna Selole Formation, Costamagna, 2016; Costamagna et al., 2007; Dieni et al., 1983) (Fig. 3).

In the Arcu Is Fronestas locality (Arcu Is Fronestas section, Fig. 6), located about $3 \mathrm{~km}$ to the NE of Escalaplano, on the road to Perdasdefogu (Fig. 1B), the Middle Triassic succession is less than $20 \mathrm{~m}$ thick. It lies unconformably over the Variscan basement and is unconformably overlain by the Middle Jurassic quartz conglomerates of the Genna Selole Formation. The section can be described as follows:

- the base of the succession consists of pinkish-reddish polygenic conglomerates and breccias and it unconformably overlies the schists of the Variscan basement (Fig. 6A). Quartz pebbles, angular clasts of metamorphic basement and Permian volcanites are supported by a sandy matrix alternating with reddish sandstones $(80 \mathrm{~cm})$;

- it follows an approximately 4 m-thick alternation of dark gray to reddish claystones and greenish-yellow marly claystones, with centimetric intercalations of medium-coarse sandstones bearing halite casts, mudcracks and bioturbation (AIF2, AIF5 pollen samples, Fig. 6A1);

- moving upwards, there is an increase in the carbonate content, resulting in the presence of reddish marls and clayey marls over claystones (10-15 m; Fig. 6B);

- dark gray-black claystones to yellowish marly claystones (5 m) (AIF 9 pollen samples, Fig. 6C) make up the upper part of the Escalaplano Formation in this area, and they are overlain by the Jurassic quartz conglomerates of the Genna Selole Formation.

\subsubsection{Campumari}

Sparse and thin "Permian-Triassic" auctt. successions unconformably cover the early Palaeozoic slightly metamorphic rocks in the Iglesiente and Arburese regions (SW Sardinia, Cocozza \& Gandin, 1976; Barca \& Costamagna, 2003a). The studied section is about $50 \mathrm{~m}$ thick and is located in the Su Passu Malu locality, along the SP83, between the villages of Nebida and Gonnesa (Fig. 7 A and Fig. 1). From the base to the top, the section shows:

- the Riu Is Corras Formation lies unconformably over the folded Variscan basement and shows marked lateral heterogeneity. The first $14 \mathrm{~m}$ of the studied section consist of yellowish calcrete, organized in thick banks, often brecciated and with evidence of calichitization processes;

- this is followed by about $8 \mathrm{~m}$ of well-cemented, heterogeneous conglomerates organized in metric strata (Fig. 7B). Subordinated, dolomitic crusts, nodular and brecciated dolomitic mudstones, rare sandstones with caliches and reddish argillaceous siltites occur; 
- the passage to the Campumari Formation lower member, i.e., the Su Passu Malu Member, is marked by $1.5 \mathrm{~m}$-thick, thinly bedded light gray mudstones. This level is followed by a conglomerate bank about $1 \mathrm{~m}$ thick, which is again followed by $2.5 \mathrm{~m}$ of gray mudstones and dolomitic mudstones, locally rich in plant debris, sulphate pseudomorphs and carbonate-rich silt intercalations (pollen sample GRIFO 3) (Fig. 7C);

- there follow $4 \mathrm{~m}$ of laminated dolostones (Fig. 7D), organized in centimetric to decimetric strata and showing bioturbation and tepee structures;

- the passage to the Campumari Formation upper member, i.e., the Grifoneddu de S'acqua Member, is marked by a collapse breccia horizon (1-2 $\mathrm{m}$ thick) (Fig. 7E) followed by massive to well-stratified dolostones, showing laminations, evidence of bioturbation (Rhyzocorallium jenense Zenker; Cocozza \& Gandin, 1976), and pseudomorphs after evaporitic minerals.

\subsection{Palynological data}

\subsubsection{Revision of previous works}

Various palynological studies have previously analyzed Anisian assemblages in Sardinia. Displaying the information in chronological order, a detailed review was attempted of the following publications: Damiani and Gandin (1973c), Pittau Demelia \& Del Rio (1980), Flaviani (1980), Pittau Demelia and Flaviani (1982a, 1982b a,b), Frechengues et al. (1993), Barca et al. (1995b), Ronchi (1997), Costamagna et al. (2000) and Pittau and Del Rio (2002).

The first reference to the presence of a Middle Triassic pollen association is found in Damiani and Gandin (1973c). These authors mentioned a productive sample collected in reddish marly layers just southwest of the village of Escalaplano (level 2 of the section that corresponds to $\mathrm{km} 47.4$ of the s.s. Nurri-Escalaplano, now SP10) (Fig. 2). At the time of the publication of Damiani \& Gandin's work, the palynological sample was being studied by Del Rio and, for this reason, the authors limited themselves to preliminarily pointing out the presence of a continental floristic association from the Middle Triassic, represented mainly by gymnosperms.

The first formal palynostratigraphic study on the Anisian of Sardinia was undertaken by Pittau Demelia \& Del Rio (1980) via a sparse and poorly preserved palynological assemblage (see the complete list of taxa in Supplementary Material) in the clay levels of the upper part of member B (sensu Cocozza \& Gandin, 1976) of the stratigraphic section of the Campumari outcrop, at km 1.7 between Funtanamare and Nebida (Fig. 2). These authors assigned to this sample a "Lower Muschelkalk" age due to the presence of Stellapollenites muelleri (=Hexasaccites muelleri), Minutosaccus crenulatus and the genus Triadispora. Although the figures do not confirm all the taxonomic attributions, we could suggest an Anisian sensu lato age through the correct identification of Hexasaccites muelleri (Visscher \& Brugman, 1981; Brugman, 1983, 1986; Diez, 2000; Kürschner \& Herngreen, 2010).

In Flaviani (1980), the palynostratigraphy from the subsurface of Nurra (Cugiareddu well, Figs. 1A, 2: 6) was presented. This is an unpublished study whose results were used at the time to make lithostratigraphic correlations between Triassic outcrops in Sardinia. In this work, new palynomorphs were described; the authorship of these new species was attributed to P. Pittau in later papers (Pittau \& Del Rio, 2002; Pittau Demelia \& Flaviani, 1982a, 1982b), and they were used only for Sardinian Triassic studies. Normally this type of publication should not be treated in the context of a review as it is unpublished research, but it has been necessary to include it due to its importance in the development of our review.

The samples used for palynostratigraphic studies in Flaviani's thesis were provided from a previous work by Pomesano Cherchi (1968) on the Cugiareddu well (Fig. 1). These samples correspond to level 545 (sample 970 in Flaviani, 1980), ascribed to the Permian; levels 477 and 443 (samples 756 and 755 respectively, in Flaviani, 1980), which Pomesano Cherchi (1968) described as "Buntsandstein" but Flaviani attributed to the Lower and Middle Muschelkalk respectively; finally, a level 429 (sample 754 in Flaviani, 1980) was described as Lower Muschelkalk by Pomesano Cherchi (1968), and later attributed to the Upper Muschelkalk by Flaviani (1980).

As for sample 970, Flaviani (1980) showed a poor assemblage (see the complete list of taxa in Supplementary Material) and ascribed it to an inconclusive Permian-Triassic age through comparison with the Germanic Zechstein associations. However, the joint appearance of the guide taxa Lueckisporites virkkiae, typical of the middle and upper Permian, and Hexasaccites muelleri that appears during the Anisian (Middle Triassic) and other Triassic taxa, such as Triadispora crassa, Enzonalasporites leschikii and Illinites sp., suggests an Anisian sensu lato age. The presence of a single specimen of Lueckisporites virkkiae would not be sufficient for any Permian affinity.

The next two associations, of samples 756 and 755 (see the complete list of taxa in Supplementary Material), were included in "Zone A": this Zone would correspond to the Lower and Middle Muschelkalk interval (Anisian). It would be characterized by the significant presence of Hexasaccites muelleri and Triadispora crassa, and the Alisporites-Cuneatisporites-Sulcatisporites bisaccate pollen morphogroup. Flaviani also differentiated two subzones: A1 (sample 756) and A2 (sample 755). Subzone A1 (Lower Muschelkalk, Anisian) would be characterized by the presence of 
Aratrisporites bulloides (n. sp. in Flaviani, 1980), Lunatisporites rhaeticus and Lunatisporites acutus. Subzone A2 (Middle Muschelkalk, Anisian) would be characterized by Myriamsporites triassicus (n. sp. in Flaviani, 1980) and Aratrisporites distalirugulatus (n. sp. in Flaviani, 1980), as well as Krauselisporites cuspidus, Aratrisporites paraspinosus, Ellipsovelatisporites plicatus, Striatiabieites aytugii and Angustisulcites klausii. As we explain in the next section, the presence of Hexasaccites muelleri would indicate an Anisian age for samples 756 and 755. Unfortunately, we believe that the sub-divisions A1 and A2 could not be justified when using new species from levels that have not been geochronologically dated or correlated with other sources previously.

Flaviani (1980) assigned the fourth association (see the complete list of taxa in Supplementary Material), referred to as sample 754 (429 m.), to the Upper Muschelkalk ("Zone B", Anisian-Ladinian transition), based on the absence of Hexasaccites muelleri and the presence of Ovalopollis pseudoalatus. However, following our methodology, we cannot endorse this datum, since we do not accept the criterion of absence.

Pittau Demelia and Flaviani (1982b) included a partial publication of the study by Flaviani (1980) of the Cugiareddu well. The featured palynomorphs are not correctly referenced, however, and neither do these authors show photos of all the listed taxa, nor any references to the studied samples. It can be deduced, solely from the wording of the text, that the specimens are the same, and the new species described in Flaviani (1980) already appear as Pittau's in Flaviani, 1980. Therefore, the same considerations applied to Flaviani (1980) can be used for Pittau Demelia and Flaviani (1982b). Some photos of taxa are included, without mentioning what level they correspond to. In this case, we can confirm the existence of Hexasaccites muelleri and the possible classification of Triadispora crassa and Prodiploxypinus gracilis, which reaffirms the notion that nothing can be said about those levels containing $\mathrm{H}$. muelleri that does not correspond to the Anisian sensu lato.

Subsequently, new palynological data (see the complete list of taxa in Supplementary Material) were described from the Punta del Lavatoio section (Fig. 1A) by Pittau Demelia and Flaviani (1982a). The authors sampled different dark clay layers located in the "Lithofacies C" (Costamagna, 2002). Due to the presence of the morphological group Alisporites-Sulcatisporites-Cuneatisporites, Triadispora crassa, Aratrisporites sp., Aratrisporites paraspinosus, Camarozonosporites cf. rudis, Polypodiaceoisporites sp. and Verrucosisporites sp, in sample 1275, coming from one of these levels, it was possible to correlate it with subzone A2 of the Cugiareddu well (Flaviani, 1980; Pittau Demelia \& Flaviani, 1982a, 1982b). With this correlation, the authors pointed out that, as in the A2 subzone defined in the Cugiareddu well (not in Punta del Lavatoio), Stellapollenites muelleri (= Hexasaccites muelleri) occurs, and so this level can be ascribed to the late Anisian, and the upper part to the early Ladinian due to the presence of Diplopora. This reasoning is not viable under our methodology because photos of only seven taxa are presented (Aratrisporites sp., Chordasporites singulicorda, Concavisporites sp., Polypodiaceoisporites sp., Striatoabieites sp., Triadispora plicata and T. suspecta). Furthermore, the determination is based on a taxon that would not even have been present in the sample.

Subsequently, Frechengues et al. (1993) described palynological results for a sample (see the complete list of taxa in Supplementary Material) in a dark clay level, included in the "Escalaplano section", which they also compare to those mentioned above by Damiani and Gandin (1973a) (Fig. 2: 4). The authors suggested a Ladinian age to this sample due to the presence of a large amount of Triadispora spp., numerous Alisporites, Pityosporites neomundanus and Cycadopites, the absence of Ovalipollis and Circumpolles and the low quantity of spores, except for Aratrisporites saturni and A. fisheri. In the same work, the authors compared this assemblage with similar ones in the Pyrenean ranges and with the association described in Pittau Demelia and Flaviani (1982a) for the section of Punta del Lavatoio. Of all the taxa referenced, only the photo of Heliosaccus dimorphus is published. This does not allow us to conclude that the classification is correct and, because of the lack of characterization of the forms presented in that work, we prefer not to attribute these levels to the Ladinian.

In Barca et al. (1995b), a well-preserved association (see the complete list of taxa in Supplementary Material) is yielded by the basal marly levels of the carbonate Case Pisano $\mathrm{Mb}$ (Punta Su Nuraxi Formation, Costamagna \& Barca, 2002) in the Scivu-Is Arenas section (Figs. 1C, 2: 2). The authors reported a very diverse palynomorph content with fifty-three different taxa, but photos of only twenty-six of these are shown. Due to the presence of Triadispora crassa, together with Illinites chitonoides, Angustisulcites klausi, Microcachrydites fastidioides, Stellapollenites thiergartii (= Hexasaccites muelleri), Perotriletes minor and Cristianisporites triangulatus, they consider that the association would be Pelsonian-Illyrian in age and would be correlated with the "phase Mu-1" of Dockter et al. (1980). Barca et al. (1995b) illustrate some taxa, but not all, to evaluate the identifications presented. According to our interpretation of the original diagnoses, we would change some of the published identifications, including Aratrisporites sp. for Cerebropollenites mesozoicus Nilsson 1958, Chordasporites singulichorda Klaus 1964 for Microcachryidites doubingeri Klaus 1964, Cuneatisporites radialis Leschik 1955 for Angustisulcites sp., Giggiospora escalaplanoi Pittau Demelia 1980 for Enzonalasporites sp., Myriamsporites triassicus Pittau Demelia in Flaviani, 1980 for Paleospongisporis europaeus 

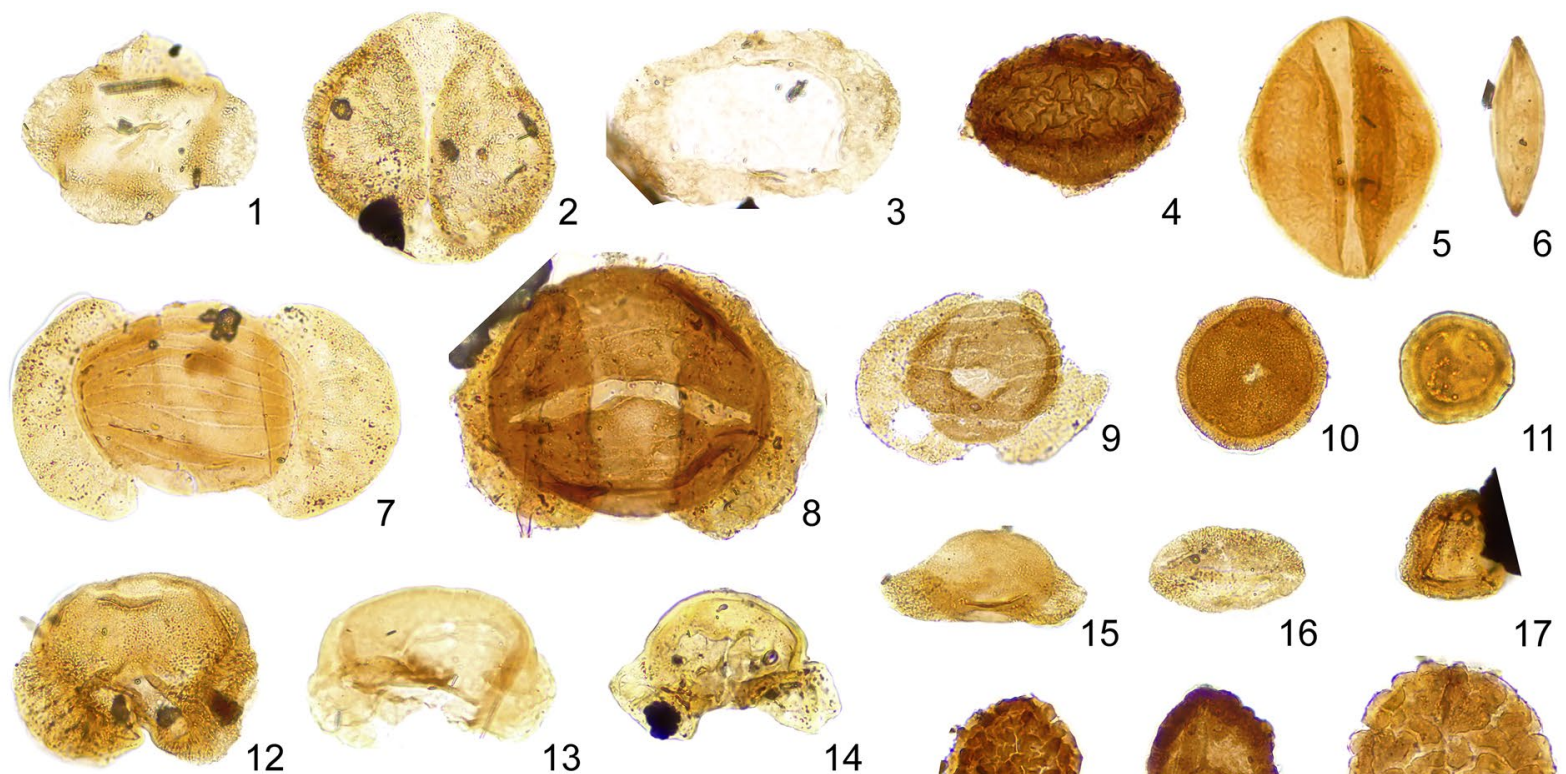

13
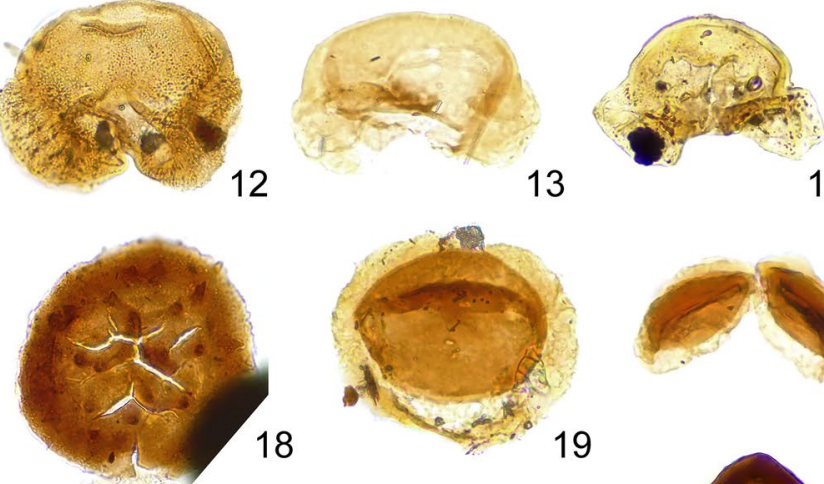

14
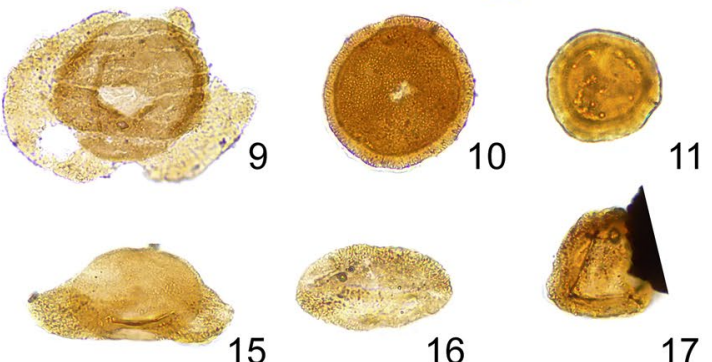

16
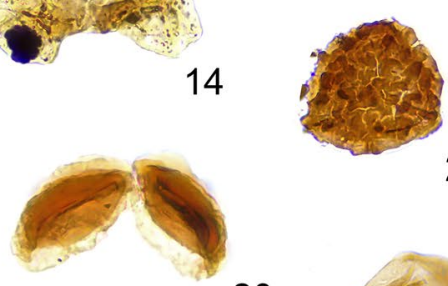

21
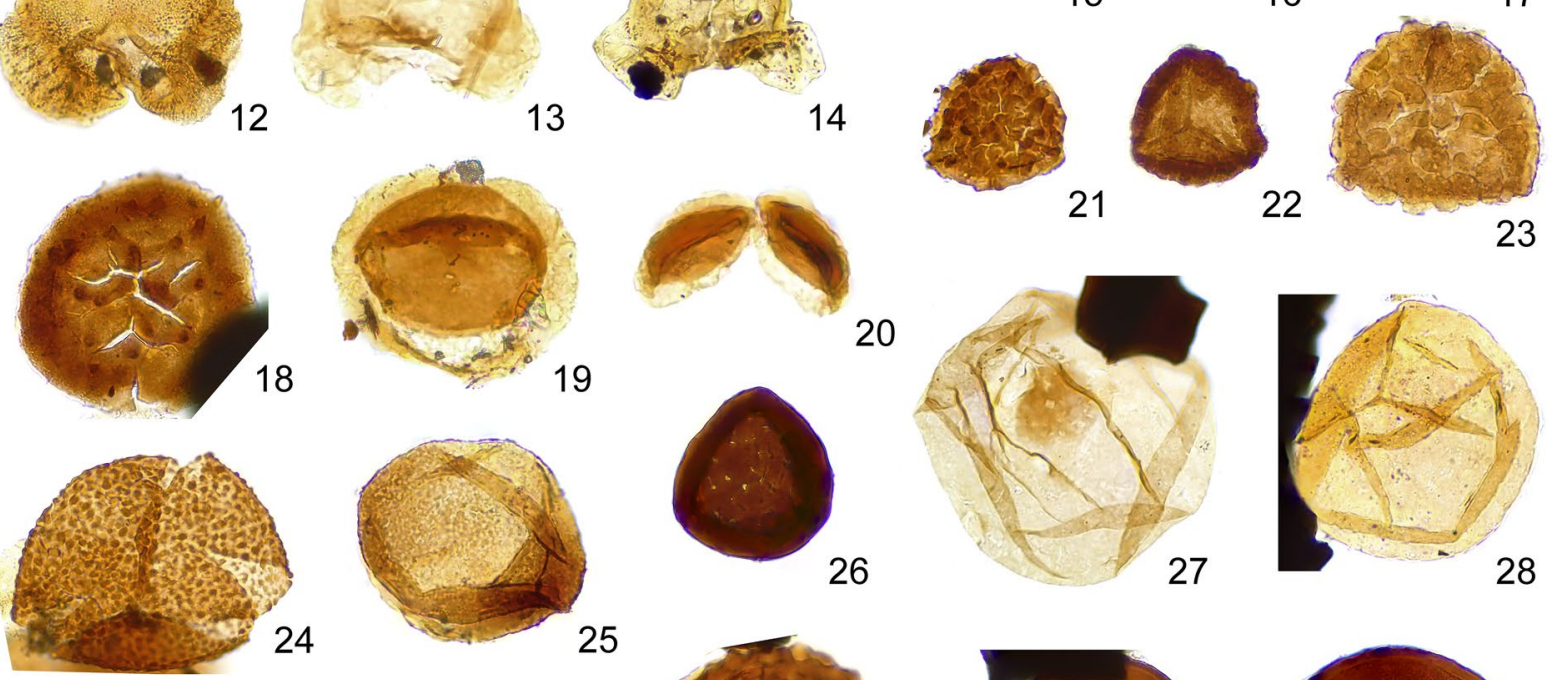

20
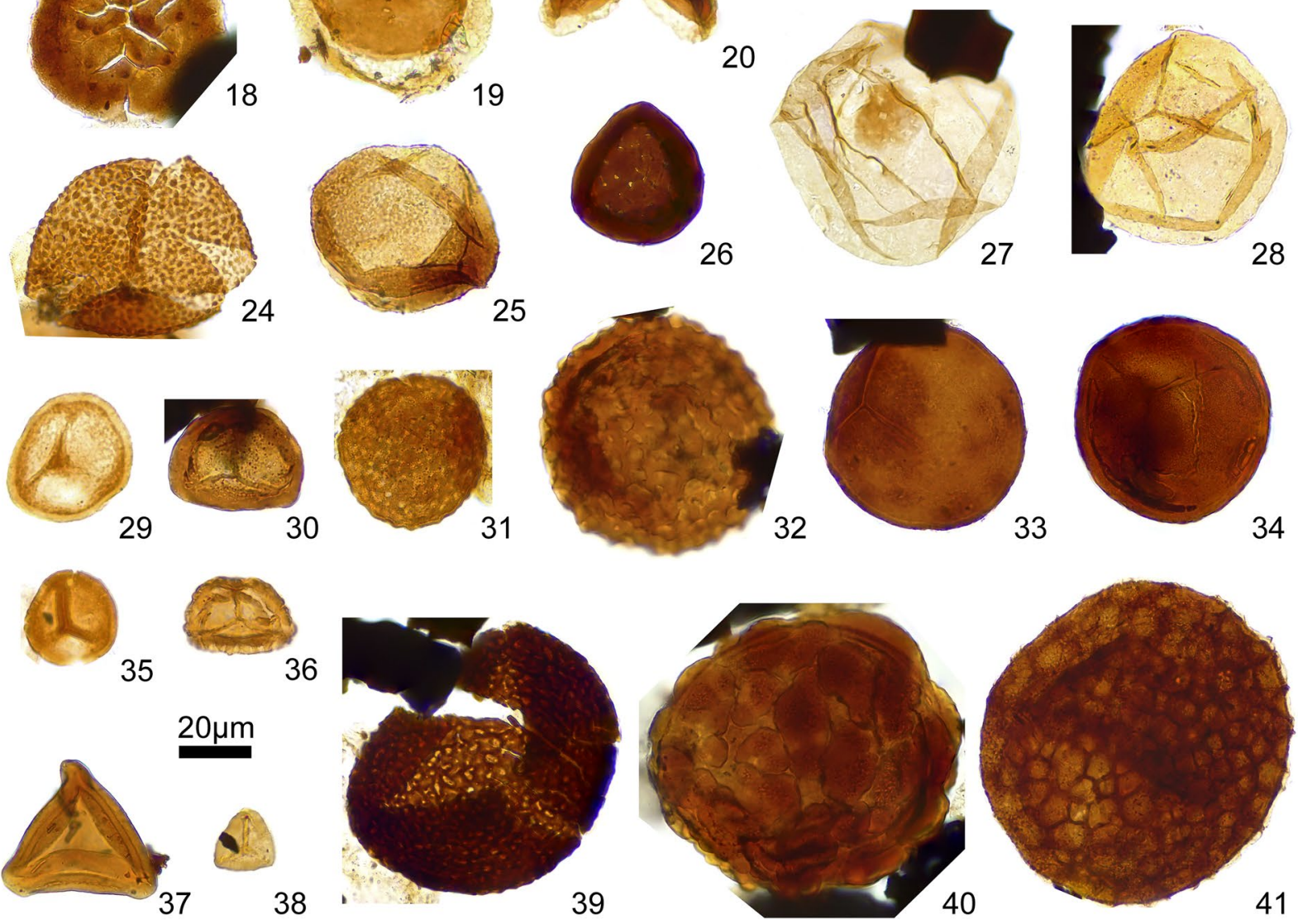

Schulz 1965, Perotriletes minor (Mädler) Antonescu \& Taugourdeau Lantz 1973 for Perotriletes sp., StellapollenTriadispora maxivestita Pittau Demelia in Flaviani, 1980 for Triadispora sp., Varirugosisporites roeticus (Schulz) Pittau Demelia in Flaviani, 1980 for Verrucosisporites sp., Verrucatosporites cugiareddu Pittau Demelia in Flaviani, 1980 for Verrucosisporites thuringiacus Mädler 1964. This cher 1966 for Strotersporites richteri (Klaus) Wilson 1962, 
4Fig. 8 Synthesis of the palynomorphs found in the Sardinian sections. Scale bar: $20 \mu \mathrm{m}$. The acronym indicates section-sample_number slide_England Finder slide coordinates. 1. Bascanisporites sp. GRIFO3_02_E154. 2. Brachisaccus neomundanus (Leschik) Mádler, 1964. 3. Cf. Cordaitina sp. GRIFO3_02_F123. 4. Cerebropollenites mesozoicus Nilsson, 1958. PC-3_B_02_H310. 5. Chasmatosporites sp. AIF-5_03_H401. 6. Cycadopites sp. AIF-5_01_M443. 7. Striatoabieites aytugii (Visscher) Scheuring, 1978. GRIFO3_01_L411. 8. Strotersporites jansonii Klaus, 1963. PC-3_B_02_T340. 9. Striatopodocarpidites cancellatus (Balme \& Hennelly) Hart, 1963. PC-3_B_01_U232. 10. Enzonalasporites vigens Leschik, 1955. PC3_B_03_N404. 11. Paracirculina sp. AIF-9_04_C173. 12. Microcachryidites doubingeri Klaus, 1964. GRIFO3_03_N163. 13. Microcachryidites fastidioides (Jansonius) Klaus, 1964. AIF-5_01_S192. 14. Microcachryidites sittleri Klaus, 1964. PC7.2_01_X352. 15. Microcachryidites sp.1. GRIFO3_01_R180. 16. Ovalipollis ovalis (Krutzsch) Scheuring, 1970. GRIFO3_01_E052. 17. Duplicisporites granulatus (Leschik) Scheuring, 1970. GRIFO3_04_K353. 18. Kraeuselisporites sp. PC-3_B_03_K294. 19. Aratrisporites cf. granulatus (Klaus) Playford and Dettmann, 1965. AIF-5_02_O301. 20. Aratrisporites sp. AIF-5_01_O094. 21. Uvaesporites sp. PC-3_B_03_ L291. 22. Rewanispora vermiculata Antonescu and TaugourdeauLantz, 1973. PC-2_B_04_W343. 23. Rewanispora sp. PC-3_B_01_ T342. 24. Cyclotriletes granulatus Mädler, 1964. PC-3_B_03_R452. 25. Cyclotriletes oligogranifer Mädler, 1964. PC-3_B_02_H270. 26. Limbosporites sp. PC-2_B_03_Q274. 27. Calamospora tener (Leschik) Mädler, 1964. PC-4_B_02_E343. 28. Calamospora sp. PC2_B_01_M520. 29. Densoisporites nejburgii (Schulz) Balme, 1970. AIF-5_03_C430. 30. Densosporites sp.PC7.2_01_W391. 31. Microreticulatisporites gallii Adloff and Doubinger, 1969. PC-4_B_02_ K250. 32. Reticulatisporites sp. PC7.2_01_R410. 33. Punctatisporites fungosus Balme, 1963. PC-3_B_01_P414. 34. Punctatisporites triassicus Schulz, 1964. PC-3_B_03_N281. 35. Camarozonosporites sp. AIF-5_04_J353. 36. Annulispora sp. GRIFO3_02_J401. 37. Dictyophyllidites mortonii (de Jersey) Playford and Dettmann, 1965. GRIFO3_01_M420. 38. Deltoidospora sp. GRIFO3_01_K262. 39. Unidentified spore PC-4_B_01_Q292. 40. Verrucosisporites thuringiacus Mädler, 1964. PC7.2_02_U432. 41. Paleospongisporis europaeus Schulz, 1965. PC-2_B_01_E472

new interpretation of the data has allowed us to specify the previous dating in the Discussion section.

In Ronchi (1997), two palynological associations (see the complete list of taxa in Supplementary Material) from samples collected in levels known as the Buntsandstein of the Triassic basin of Escalaplano were studied by Pittau. The ARPE-02 sample was obtained at the northeast of the basin (Arcu Is Fronestas) along the Escalaplano-Perdasdefogu road and the ARPE-04 sample at the southern entrance to Escalaplano (Fig. 1B). Both levels were attributed to the Anisian by Pittau (A. Ronchi Pers. Com.), as the presence of Stellapollenites thiergartii is referable to Anisian. Unfortunately, we cannot make any assessment as the work does not present any photos of the taxa mentioned.

In order to formalize the Escalaplano Formation, Costamagna et al. (2000) described three levels with palynomorphs (see the complete list of taxa in Supplementary Material) of two different sections of the "lithofacies B": two levels in a section (nowadays covered by a road wall) not far from the southern entrance to the village of
Escalaplano - along the Escalaplano-Orroli road, 2 and $4 \mathrm{~m}$ from the underlying contact on the Palaeozoic basementand the third level along a cut on the Escalaplano-Perdasdefogu road in the locality of Arcu Is Fronestas. Based on the presence of Stellapollenites muelleri, Cristianisporites triangulatus and Dyupetalum vicentinense, these levels were considered upper Anisian (Pelsonian), correlating with the "vicentinense-muelleri" phase, according to Brugman (1986), Visscher and Brugman (1981) and Van Der Eem (1983), and the Escalaplano Fm is thus upper Anisian-basal Ladinian.

Observation of the photographs allows us to verify the referenced taxa and propose a new attribution for some of them, as appropriate. We consider that the form attributed to Dyupetallum vicentinense could also be Cristianisporites triangulatus, among others (see supplementary material). According to the authors, the coexistence of these taxa would justify a late Anisian (Pelsonian-Illyrian interval) to early Ladinian attribution. Unfortunately, it is impossible to know the stratigraphic relationship between the studied samples and their relative position since these authors do not provide separate lists and do not attribute their published photos to specific sampled levels.

The last published reference would be Pittau and Del Rio (2002), in which the authors publish a compilation of all the previous palynostratigraphic works on the Permo-Triassic sequences of Sardinia. For the Scythian to early Anisian interval, the authors refer to a listed association (with only three photos, however) consisting of Enzonalasporites leschikii Mädler 1964, Microcachryidites fastidiosus Jansonius 1962, Sulcatisporites splendens Leschik 1955, Triadispora crassa Klaus 1964, cf. Stellapollenites muelleri (Reinardt \& Schmitz) Pittau Demelia 1993 and Voltziaceosporites heteromorpha Klaus 1964. This is the same association first described by Flaviani (1980) and related to the Permian in Pittau Demelia and Flaviani (1982b) for level 545 (sample 970). In this work, the authors reevaluate this pollen association and consider a possible Olenekian (late Scythian) or, more probably, early Anisian due to the impossibility of affirming the identification of Stellapollentes muelleri (=Hexasaccites muelleri). However, Voltziaceaesporites heteromorpha made its first appearance in the late Olenekian, according to Brugman (1986). This deduction based on the criterion of absence is not acceptable, and therefore the attribution of level to the "Scythian" is similarly unacceptable. The following section of this compilation is dedicated to the Anisian and it repeats the arguments presented in Pittau Demelia \& Flaviani, (1982b), Barca et al. (1995b), Pittau \& Del Rio, (2002) and Costamagna et al. (2000). 

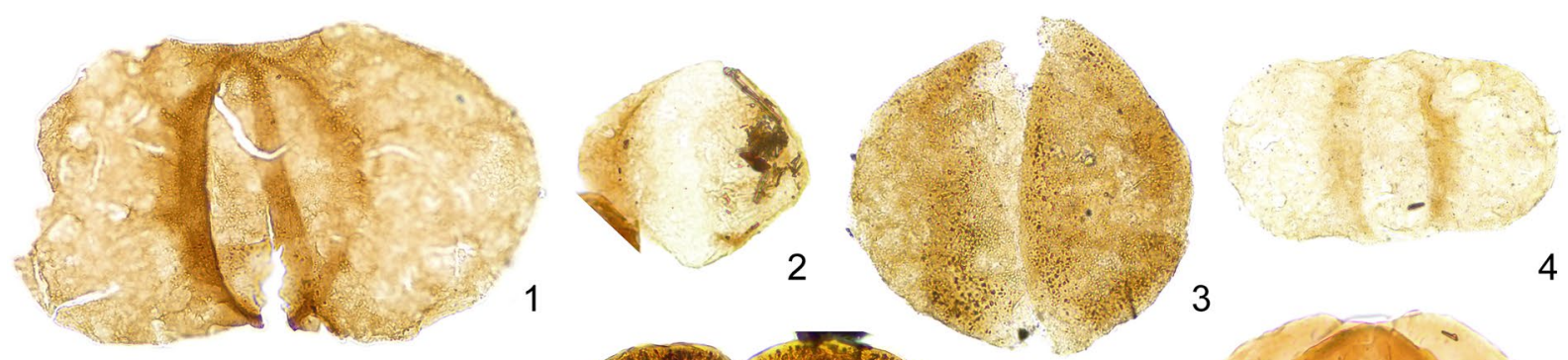

4
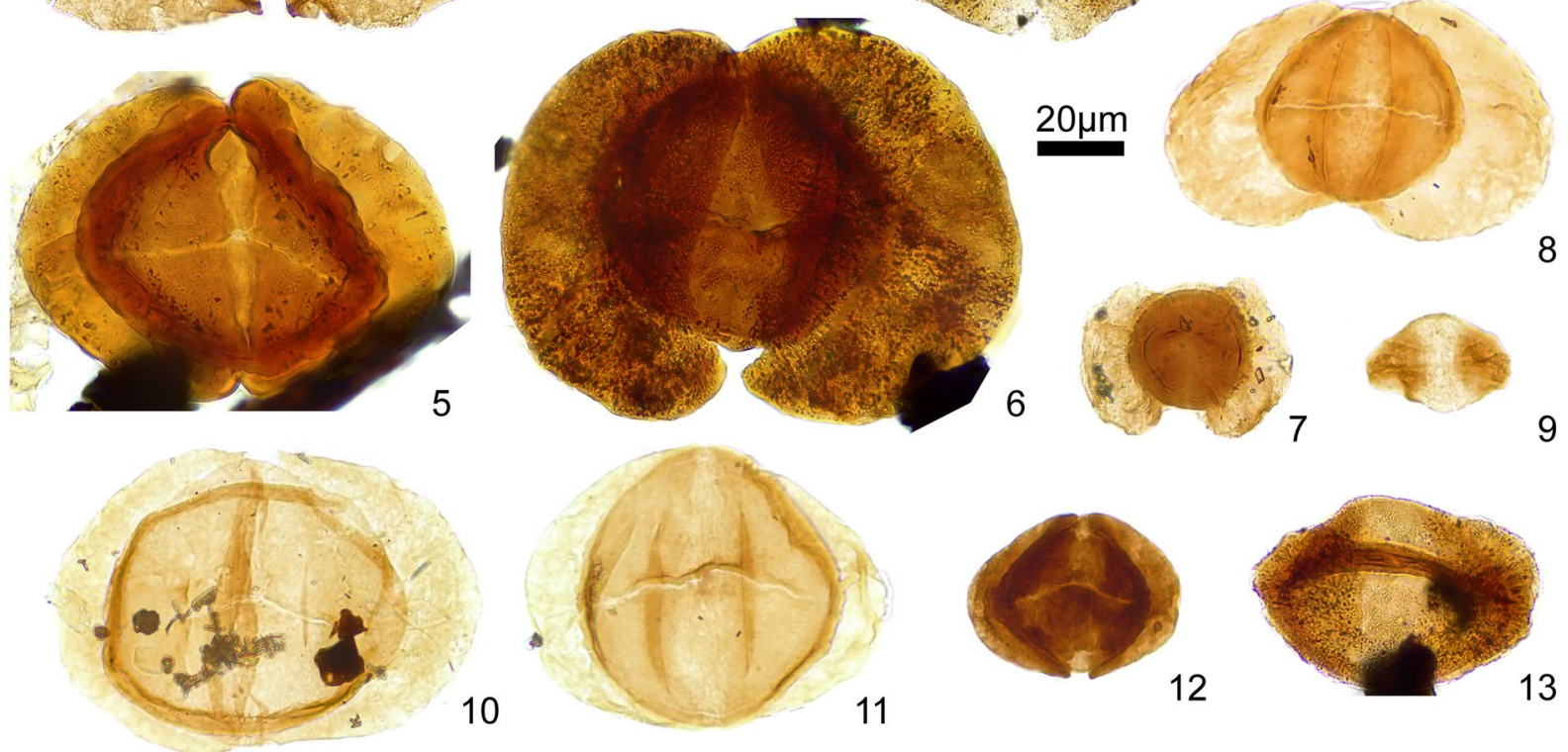

8

12

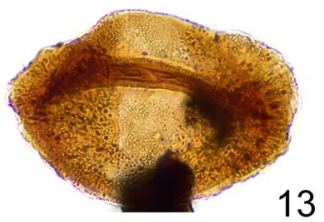

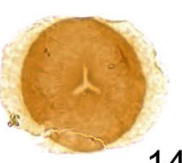
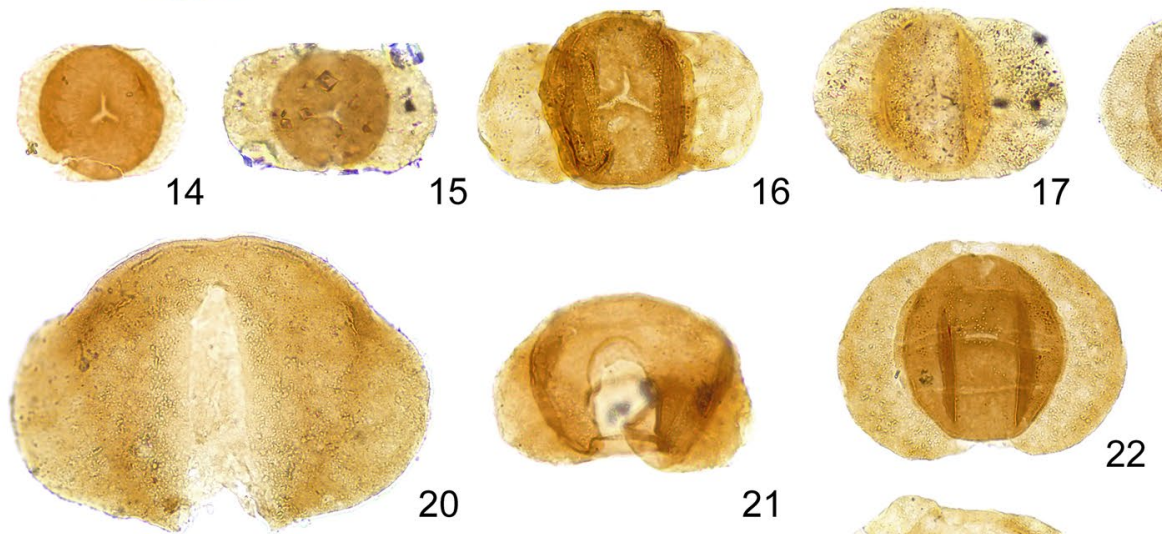

20

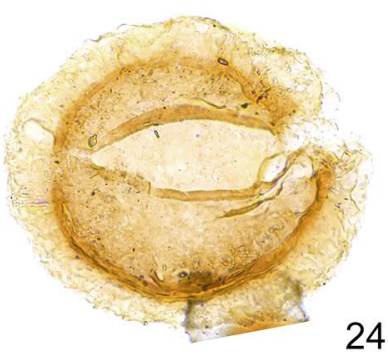

24

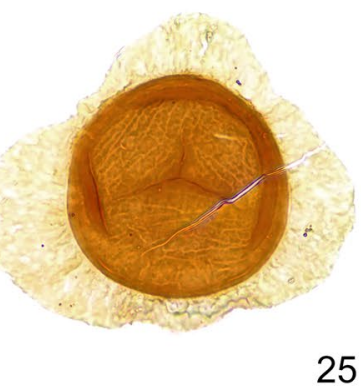

21
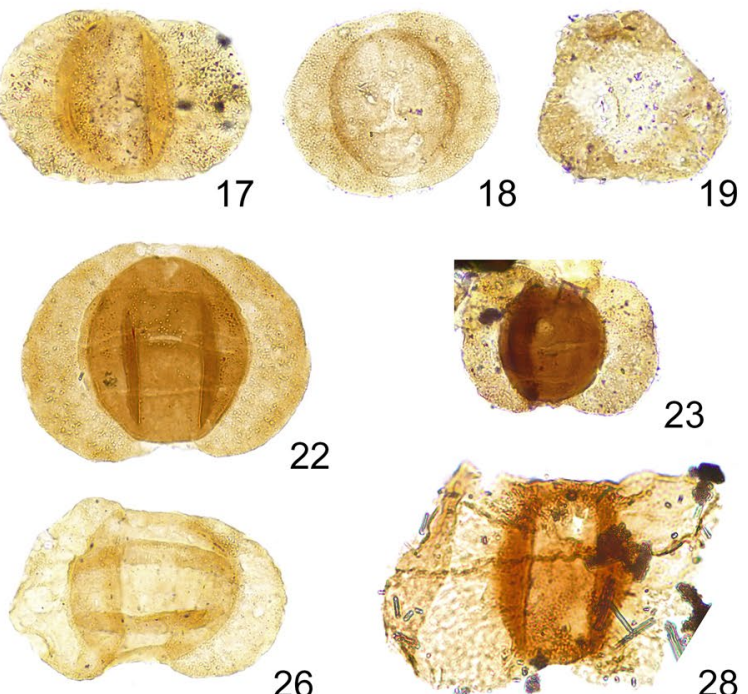

26

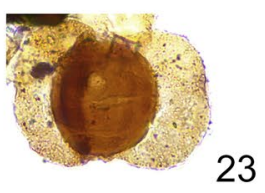

23
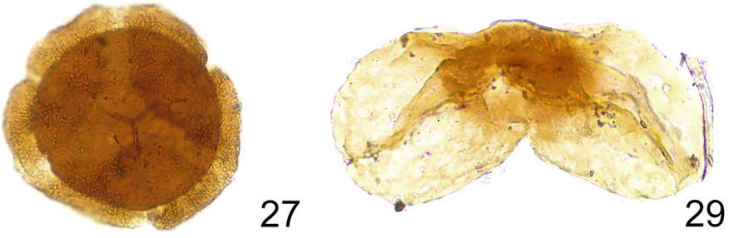

\subsubsection{Reexamined and new palynological data}

The original palynological slices analyzed in Diez (2000) have been revised and re-photographed with better image capture systems, offering a slightly more comprehensive taxa list. These slices correspond to samples PC-2, PC-3, PC-4 ("Escalaplano SW", Fig. 5) and PC-7.2 ("Arcu is Fronestas" section, Fig. 6). 
4Fig. 9 Synthesis of the palynomorphs found in the Sardinian sections. Scale bar: $20 \mu \mathrm{m}$. The acronym indicates section-sample_number slide_England Finder slide coordinates. 1. Alisporites magnus Jain 1968. PC-3_B_03_K234. 2. Alisporites grauvogeli Klaus, 1964. AIF-5_04_N151. 3. Alisporites opii Daugherty, 1941. PC7.2_01_ U424. 4. Alisporites sp. PC-4_B_03_K380. 5. Angustisulcites klausii (Freudenthal) Visscher, 1966. PC-4_B_01_M324, 6. Angustisulcites grandis (Freudenthal) Visscher, 1966. PC-2_B_01_V350. 7. Angustisulcites sp. GRIFO3_01_J052. 8. Angustisulcites gorpii Visscher, 1966. AIF-5_02_H193. 9. Vitreisporites sp. AIF-5_04_M040. 10. Illinites chitonoides Klaus, 1964. AIF-5_04_L211. 11. Illinites kosankei Klaus, 1964. AIF-5_01_R370, 12. Illinites sp. AIF-5_01_ N221. 13. Chordasporites singulichorda Klaus, 1960. PC-2_B_01_ H402. 14. Triadispora plicata Klaus, 1964. AIF-5_02_L363. 15. Triadispora crassa Klaus, 1964. PC-3_02_O414. 16. Triadispora falcata Klaus, 1964. PC-04_B_03_O400. 17. Triadispora staplinii (Jansonius) Klaus, 1964. PC7.2_02_F360. 18. Triadispora suspecta Scheuring, 1970. PC-3_B_01_D274. 19. Triadispora sp. (Three-saccated anomalous form) PC-3_01_U434. 20. Klausipollenites schaubergeri (Potonié and Klaus) Jansonius, 1962, 21. Klausipollenites sp. AIF5_01_M480. 22. Lunatisporites acutus Leschik, 1955. PC-4_B_03_ X480. 23. Lunatisporites cf. puntii Visscher, 1966. PC-3_01_O313, 24. Heliosaccus cf. dimorphus. Mädler, 1964. PC-4_B_02_Q411. 25. Cristianisporites triangulatus Antonescu, 1969. AIF-5_02_R500. 26. Lunatisporites noviaulensis (Leschik) de Jersey, 1979. 27. Hexasaccites muelleri (Reinhardt and Schmitz) Adloff and Doubinger, 1969 (=Stellapollenites thiergartii (Mädler) Clement-Westerhof et al. 1974). PC-2_B_04_W351. 28. Platysaccus leschikii Hart, 1960. AIF2_01_S273, 29. Platysaccus papilionis Potonié and Klaus, 1954. PC3_B_03_M352

Palynological analyses from different Sardinian outcrops, including the Escalaplano section, have recently been performed. New productive samples (AIF-2, AIF-5 and AIF-9) were obtained in the "Arcu is Fronestas" section (Fig. 2: 3 and Fig. 6) to complete the information of Diez (2000). Moreover, a new sample was obtained in $\mathrm{Su}$ Passu Malu (Campumari) (Grifo 3, Figs. 2: 1 and 7).

Synthetic plates of all the samples studied are presented (Figs. 8 and 9). The complete palynological assemblages are shown in the supplementary material (Table 1 and Figs. S1-S8). Based on the taxonomic similarity of the palynomorph assemblages found and their stratigraphic location, these assemblages have been grouped into several synthetic associations indicating the same age.

The synthetic association of the Escalaplano southern entrance is the "Escalaplano SW Section" (Figs. 1B, 5), corresponding to the C-2, PC-3 and PC-4 samples and composed of: Alisporites grauvogeli Klaus, 1964, Alisporites magnus Jain 1968, Alisporites opii Daugherty, 1941, Alisporites sp., Angustisulcites grandis (Freudenthal) Visscher, 1966, Angustisulcites klausii (Freudenthal) Visscher, 1966, Aratrisporites sp., Calamospora tener (Leschik) Mädler, 1964, Calamospora sp., Chasmatosporites sp., Cerebropollenites mesozoicus Nilsson, 1958, Chordasporites singulichorda Klaus, 1960, Cyclotriletes oligogranifer Mädler, 1964, Cyclotriletes granulatus Mädler, 1964, Enzonalasporites vigens Leschik, 1955,
Heliosaccus cf. dimorphus. Mädler, 1964, Hexasaccites muelleri (Reinhardt \& Schmitz) Adloff \& Doubinger, 1969, Illinites kosankei Klaus, 1964, Illinites chitonoides Klaus, 1964, Klausipollenites schaubergeri (Potonié and Klaus) Jansonius, 1962, Kraeuselisporites sp., Limbosporites sp., Lunatisporites acutus Leschik, 1955, Lunatisporites noviaulensis (Leschik) de Jersey, 1979, Lunatisporites cf. puntii Visscher, 1966, Microcachryidites doubingeri Klaus, 1964, Microcachryidites fastidioides (Jansonius) Klaus, 1964, Microreticulatisporites gallii Adloff \& Doubinger, 1969, Paleospongisporis europaeus Schulz, 1965, Platysaccus papilionis Potonié and Klaus, 1954, Platysaccus sp., Punctatisporites fungosus Balme, 1963, Punctatisporites triassicus Schulz, 1964, Rewanispora vermiculata Antonescu and Taugourdeau-Lantz, 1973, Rewanispora sp., Striatoabieites aytugii (Visscher) Scheuring, 1978., Striatopodocarpidites cancellatus (Balme \& Hennelly) Hart, 1963, Strotersporites jansonii Klaus, 1963, Triadispora crassa Klaus, 1964, Triadispora falcata Klaus, 1964, Triadispora plicata Klaus, 1964, Triadispora staplinii (Jansonius) Klaus, 1964, Triadispora suspecta Scheuring, 1970, Triadispora sp.1., Uvaesporites sp., Verrucosisporites sp.1. and two unidentified spores.

The samples from the "Arcu Is Fronestas" section can be grouped into two synthetic associations. The first corresponds to the AIF-2 and AIF-5 samples collected in the lower part of the section (Fig. 6) and is composed of: Alisporites grauvogeli Klaus, 1964, Alisporites magnus Jain 1968, Alisporites opii Daugherty, 1941, Alisporites sp., Angustisulcites gorpii Visscher, 1966, Angustisulcites klausii (Freudenthal) Visscher, 1966, Angustisulcites sp., Aratrisporites cf. granulatus (Klaus) Playford \& Dettmann, 1965, Aratrisporites sp., Brachisaccus neomundanus (Leschik) Mädler, 1964, Camarozonosporites sp., Chasmatosporites sp., Chordasporites singulichorda Klaus, 1960, Cristianisporites triangulatus Antonescu, 1969, Cycadopites sp., Densoisporites nejburgii (Schulz) Balme, 1970, Enzonalasporites vigens Leschik, 1955, Hexasaccites muelleri (Reinhardt \& Schmitz) Adloff \& Doubinger, 1969, Illinites chitonoides Klaus, 1964, Illinites kosankei Klaus, 1964, Illinites sp., Klausipollenites sp., Kraeuselisporites sp., Lunatisporites noviaulensis (Leschik 1956) DE Jersey, 1979, Microcachryidites doubingeri Klaus, 1964, Microcachryidites fastidioides (Jansonius) Klaus, 1964, Microcachryidites sp., Paracirculina sp., Platysaccus leschikii Hart, 1960., Platysaccus sp., Punctatisporites fungosus Balme, 1963, Rewanispora vermiculata Antonescu \& TaugourdeauLantz, 1973, Triadispora crassa Klaus, 1964, Triadispora plicata Klaus, 1964, Triadispora staplinii (Jansonius) Klaus, 1964, Triadispora suspecta Scheuring, 1970, Triadispora sp., Uvaesporites sp., Vitreisporites sp. and one unidentified spore. 
The second synthetic association of the section "Arcu Is Fonestas" corresponds to the samples AIF-9 and PC-7.2 extracted from the upper part of the Buntsandstein facies, just under the Jurassic quartz-conglomerates (Fig. 6). They are represented by: Alisporites grauvogeli Klaus, 1964, Alisporites opii Daugherty, 1941, Alisporites sp., Angustisulcites klausii (Freudenthal) Visscher, 1966, Angustisulcites sp., Calamospora tener (Leschik) Mädler, 1964, Calamospora sp., Cerebropollenites mesozoicus Nilsson, 1958, Chordasporites singulichorda Klaus, 1960, Cristianisporites triangulatus Antonescu, 1969, Cycadopites sp., Cyclotriletes oligogranifer Mädler, 1964, Cyclogranisporites sp., Densosporites sp., Enzonalasporites vigens Leschik, 1955, Hexasaccites muelleri (Reinhardt \& Schmitz) Adloff \& Doubinger, 1969, Illinites chitonoides Klaus, 1964, Illinites kosankei Klaus, 1964., Kraeuselisporites sp., Lunatisporites acutus Leschik, 1955, Lunatisporites sp., Microcachryidites doubingeri Klaus, 1964, Microcachryidites fastidioides (Jansonius) Klaus, 1964, Microcachryidites sittleri Klaus, 1964, Microcachryidites sp.1., Paracirculina sp., Platysaccus papilionis Potonié \& Klaus, 1954, Punctatisporites triassicus Schulz, 1964, Rewanispora vermiculata Antonescu \& Taugourdeau-Lantz, 1973, Reticulatisporites sp., Striatoabieites aytugii (Visscher) Scheuring, 1978, Striatoabieites sp., Strotersporites jansonii Klaus, 1963, Triadispora crassa Klaus, 1964, Triadispora falcata Klaus, 1964, Triadispora plicata Klaus, 1964, Triadispora staplinii (Jansonius) Klaus, 1964, Triadispora suspecta Scheuring, 1970, Triadispora sp., Uvaesporites sp., and Verrucosisporites thuringiacus Mädler, 1964.

The last association, which corresponds to the Grifo-3 sample from the Su Passu Malu section (Fig. 1D, 7), is composed of: Alisporites grauvogeli Klaus, 1964, Alisporites opii Daugherty, 1941, Angustisulcites gorpii Visscher, 1966, Angustisulcites sp., Annulispora sp., Aratrisporites cf. granulatus (Klaus) Playford and Dettmann 1965, Bascanisporites sp., Brachisaccus neomundanus (Leschik) Mädler, 1964, Calamospora tener (Leschik) Mädler, 1964, Calamospora sp., Chasmatosporites sp., Cerebropollenites mesozoicus Nilsson, 1958, Chordasporites singulichorda Klaus, 1960, Cf. Cordaitina sp., Cristianisporites triangulatus Antonescu, 1969, Cyclogranisporites granulatus Mädler, 1964, Deltoidospora sp., Dictyophyllidites mortonii (De Jersey) Playford \& Dettmann, 1965, Duplicisporites granulatus (Leschik) Scheuring, 1970, Enzonalasporites vigens Leschik, 1955, Hexasaccites muelleri (Reinhardt \& Schmitz) Adloff \& Doubinger, 1969, Illinites chitonoides Klaus, 1964, Kraeuselisporites sp., Lunatisporites noviaulensis (Leschik) De Jersey, 1979, Lunatisporites sp., Microcachryidites doubingeri Klaus, 1964, Microcachryidites fastidioides (Jansonius) Klaus, 1964, Microcachryidites sp.1., Ovalipollis ovalis (Krutzsch) Scheuring, 1970, Paleospongisporis europaeus Schulz, 1965, Paracirculina sp.,
Rewanispora vermiculata Antonescu \& Taugourdeau-Lantz, 1973, Rewanispora sp., Striatoabieites aytugii (Visscher) Scheuring, 1978, Triadispora crassa Klaus, 1964, Triadispora falcata Klaus, 1964, Triadispora plicata. Klaus, 1964, Triadispora staplinii (Jansonius) Klaus, 1964, Triadispora suspecta Scheuring, 1970, Triadispora sp., Uvaesporites sp., Verrucosisporites thuringiacus Mädler, 1964, and Verrucosisporites $\mathrm{sp}$.

\section{Palynostratigraphical discussion}

From the set of results obtained from the review of previous works, as well as from unpublished data and new pollen samples, we can infer that there has been no palynological dating corresponding to the Early Triassic in Sardinia, in contrast with neighbouring paleogeographical regions such as the Iberian Peninsula (Diez et al., 2005) and the South of France (Diez, 2000).

Furthermore, sample 1275 collected in the section of Punta del Lavatoio (Pittau Demelia \& Flaviani, 1982a) shows photos of only seven taxa and, although the authors initially ascribed it to the Anisian, this age is not consistent. The three species identified have a wide biozone distribution: Chordasporites singulichorda, which corresponds with the base of the Anisian to the Longobardian (Eshet, 1990); Triadispora plicata, from the Anisian to the Carnian; and Triadispora suspecta, from the Pelsonian to the Carnian (Doubinger \& Adloff, 1983). Therefore, our dating would be broader, and a Pelsonian-Longobardian interval is proposed for this sample (Fig. 10). A later publication by Posenato et al. (2002) studied the same outcrop and, through biostratigraphic analyses of various groups of marine invertebrates, attributed the entire section to the Ladinian. Likewise, palynological data from the same Muschelkalk facies from the Monte di Santa Giusta section to the north of Alghero (Carrillat et al., 1999) are consistent with this proposed age. Therefore, since our study is focused on the Anisian, the work of Pittau Demelia \& Flaviani (1982a) has not been considered.

As regards the rest of the works referred to in our study, it has been possible to verify the presence of Hexasaccites muelleri, which indicates that all levels can be dated as being of the Anisian age (Visscher \& Brugman, 1981; Brugman, 1983; Diez, 2000; Diez et al., 2005; Kürschner \& Herngreen, 2010).

Regarding the Cugiareddu well (Fig. 10), although most of the Flaviani (1980) work remains unpublished, the few photos published in Pittau Demelia and Flaviani (1982b) and Pittau and Del Rio (2002) allow us to address the following arguments. In their final work of compilation (Pittau \& Del Rio, 2002), the authors reevaluated the palynological association, first described by Flaviani 


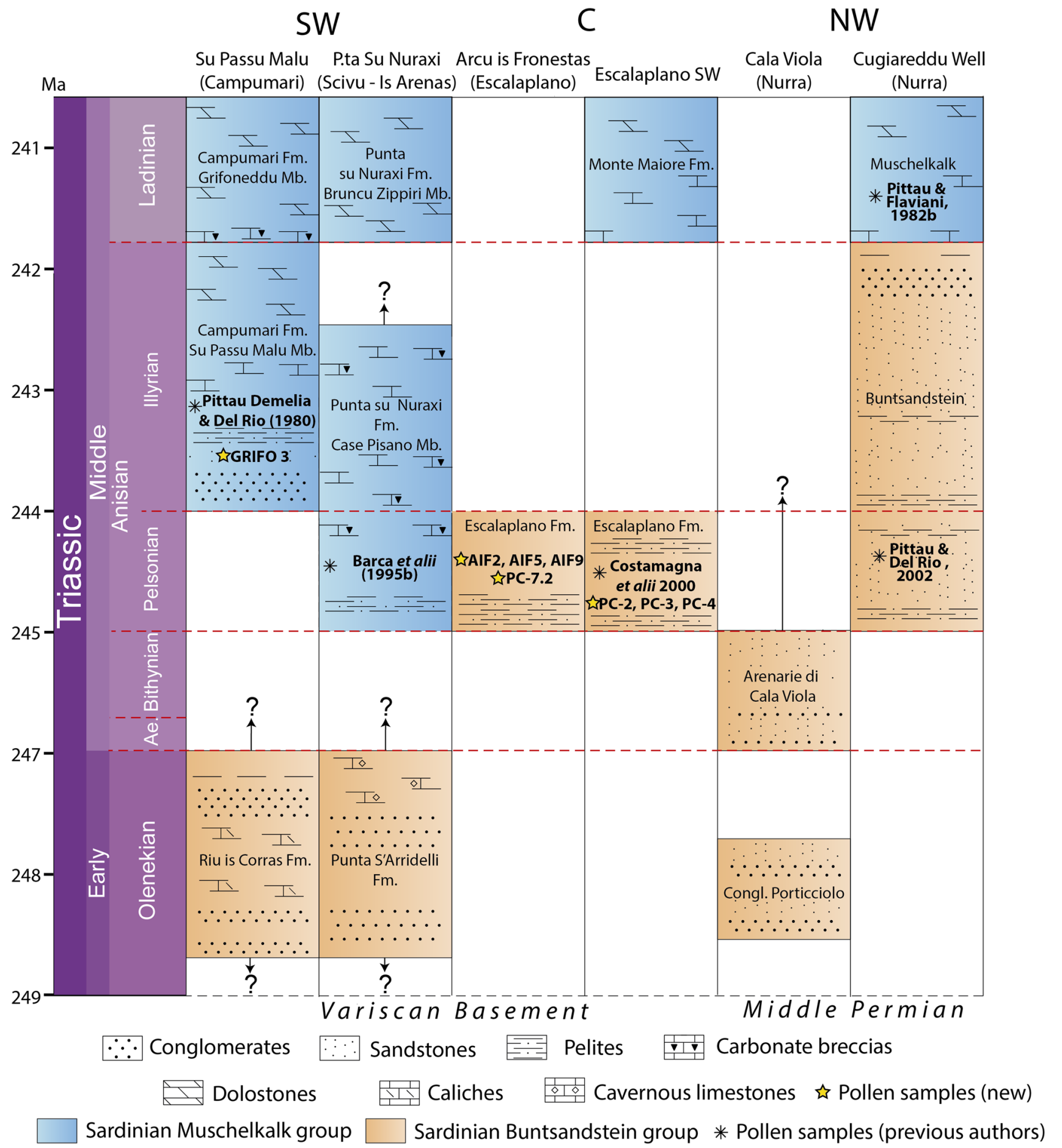

Fig. 10 Chronostratigraphic scheme of the studied succession in SW, C and NW Sardinia.

(1980) and referred to in Pittau Demelia and Flaviani (1982b), for level 545 (sample 970), and considered it a possible late Scythian or early Anisian, due to the impossibility of confirming the identification of Stellapollentes muelleri (=Hexasaccites muelleri). However, Voltziaceaesporites heteromorpha made its first appearance in the upper Olenekian, according to Brugman (1986). As we said before, the criterion of absence is not acceptable, but since this publication presents photos of three taxa we can infer from the text that they come from level 545. For this reason, we can confirm the identification of Triadispora crassa and Voltziaceaisporites heteromorpha. Therefore, 
we agree that $V$. heteromorpha begins in the upper Scythian, but its biozone extends to the Pelsonian (Brugman, 1983, 1986; Diez, 2000; Visscher \& Brugman, 1981) (Fig. 10). Furthermore, the Triadispora crassa biozone extends from the Anisian to the base of the Carnian. If we add the fact that the association is very poor based on the above, we can only say that it is Anisian without much precision and possibly does not extend to Illyrian.

In Pittau and Del Rio (2002), levels 477 (sample 756) and 443 (sample 755) of the Cugiareddu well are related to photos of Hexasaccites muelleri, corresponding with the Anisian, as mentioned above, while Cristianisporites triangulatus corresponds with a biozone between the Pelsonian (Anisian) and Fassanian (Ladinian) (Antonescu, 1969; Diez, 2000; Doubinger \& Adloff, 1983), which would place these two levels within the Pelsonian-Illyrian interval (late Anisian).

Regarding level 429 (sample 754), we reject the use of the criterion of absence. Moreover, the presence of Ovalopollis pseudoalatus, with a photo in Pittau and Del Rio (2002), does not allow us to say that the level is later than the base of the Pelsonian (Brugman, 1983; Diez, 2000; Doubinger \& Bühmann, 1981; Visscher \& Brugman, 1981) or be more specific.

Most of the published works (e.g., Pittau Demelia \& Del Rio, 1980; Ronchi, 1997; Costamagna et al., 2000 and Diez, 2000), as well as the new data presented in this work, refer to the outcrops of the Sarcidano-Gerrei region. Nevertheless, as we have already explained in the previous section, the data presented in Pittau Demelia \& Del Rio (1980), Ronchi (1997), Costamagna et al. (2000) cannot be used, due to their incomplete or non-existent sheets of photographs or the unknown stratigraphic locations (level and section) of each of the taxa photographed and classified. We could only attribute all the levels of these sections to the Anisian for the reasons mentioned above (Fig. 10).

The revised and new levels are collected in the sections of Escalaplano (Figs. 1B, 5) and Arcu Is Fronestas (Fig. 6). In the Escalaplano section, the three samples do not present a very different composition and they have been treated as a single synthetic association (for more details, see the supplementary material). If we consider the main Triassic palynostratigraphic works on the Western peryTethys domain (Doubinger \& Bühmann, 1981; Visscher \& Brugman, 1981; Brugman, 1983; Eshet, 1990; Diez et al. 2010), Enzonalasporites vigens, Microcachrydites doubingeri, Microcachryidites fastidioides, Triadispora crassa and Triadispora staplinii are consistent with the Anisian dating provided by Hexasaccites muellleri. Cyclotriletes oligogranifer, Illinites chitonoides, Triadispora plicata, and Triadispora suspecta made their first appearance in the Pelsonian (Doubinger \& Adloff, 1983; Eshet, 1990), Punctatisporites triassicus was usually present until the Pelsonian (Doubinger
\& Buhmann, 1981) and, finally, Illinites kosankei was last recorded in the middle Pelsonian (Doubinger \& Adloff, 1983) levels of facies, so we can infer that the Buntsandstein facies levels of the Escalaplano Section were deposited during the lower Pelsonian. We report the appearance of a single specimen of Heliosaccus cf. dimorphus Mädler 1964 in sample 3, in poor conditions. This species is considered to have its first record in the Anisian-Ladinian transition (Doubinger \& Adloff, 1983; Visscher \& Brugman, 1981; Brugman, 1983; Kurscher \& Herngreen, 2010), and if it is confirmed, we should reconsider its biozone (Fig. 10).

The second section studied in the Escalaplano basin is called Arcu Is Fronestas (Figs. 1D, 6). Four samples were studied but, as mentioned in the previous section, they have been unified in two synthetic associations (see the complete lists of the samples in the supplementary material,) due to their composition and stratigraphic position. The first corresponds to the lower part of the sedimentary unit in Buntsandstein facies composed of samples AIF-2 and AIF-5, and the second to the upper part composed of samples PC-7.2 AIF-9. The two synthetic associations present few differences between them; both can be attributed to the lower Pelsonian, following the same reasoning used for those of Escalaplano, and based on the same taxa sets. The only appreciable difference is the appearance of Cristianisporites triangulatus in the upper-part association, which has its first record in Central Europe in the Pelsonian (Doubinger \& Adloff, 1983). Its presence does not allow us to say that the age is more modern than the base samples, but its relative stratigraphic position could be used as a correlation criterion with the Grifo-3 sample in Campumari Section, which also presents this taxon (Fig. 10).

In the Iglesiente region (Fig. 1), the first reference is that of Pittau Demelia \& Del Rio (1980), in which a poor association is described for the Campumari outcrop. Due to the presence of Hexasaccites muelleri, the sampled unit can be attributed to Anisian sensu lato, as suggested by the authors (Fig. 10). We can confirm this attribution thanks to the photo of the taxon, as discussed in the previous section.

Furthermore, in the same region, we carried out a new sampling with a productive result in the section of Su Passu Malu (Figs. 1D, 7), where, as we reported in the previous section, a rich well-preserved Anisian palynological association with Cristianisporites triangulatus, Enzonalasporites vigens, Illinites chitonoides, Triadispora falcata, T. plicata and T. falcata together with Hexasaccites muelleri would indicates a Pelsonian-Illyrian age (Brugman, 1983; Diez, 2000; Doubinger \& Adloff, 1983; Visscher \& Brugman, 1981), which would be restricted by the presence of Duplicisporites granulatus, whose genus has its first record in Illyrian.

The presence of Enzonalasporites vigens and Duplicisporites granulatus according to Cirilli (2010) and Mietto et al. 


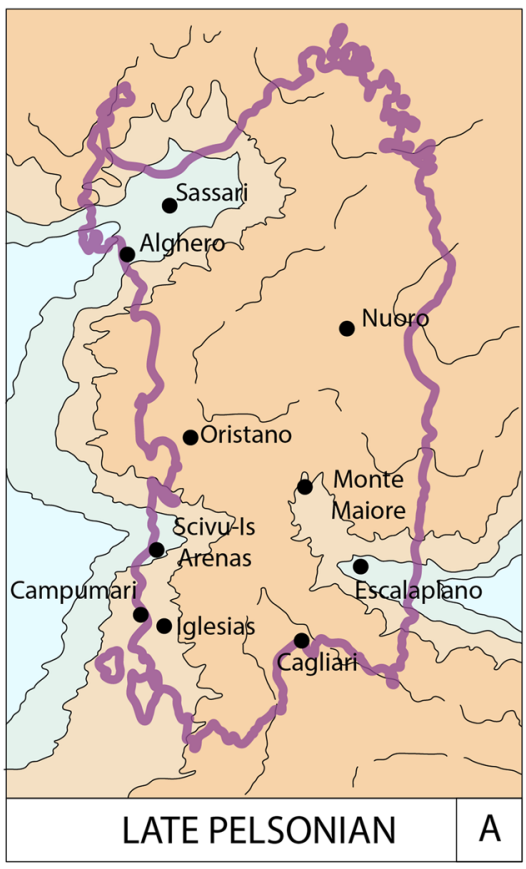

Continental sedimentation
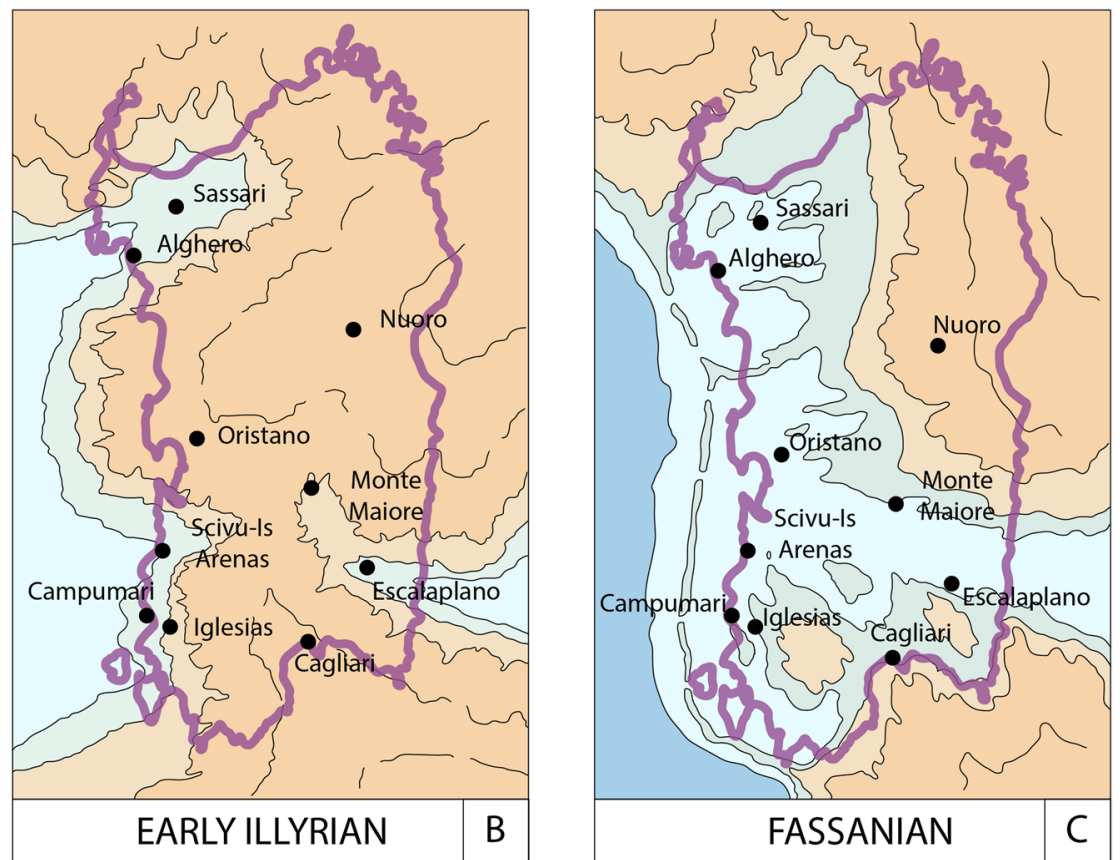

Coastal plain Sabkha

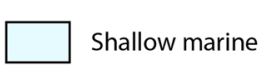

Deep marine

Fig. 11 Three stages of paleogeographic evolution in Sardinia during the Middle Triassic, modified from Costamagna \& Barca, 2002

(2012) could indicate a Ladinian age. However, Doubinger and Bühmann (1981) indicate Enzonalasporites spp. from the lower Anisian and Doubinger and Adloff (1983) indicate that Dupliciporites spp. appear from the Illyrian (upper Anisian). Of all the Anisian associations described in Sardinia, this represents the most modern level (Fig. 10).

In addition to the data presented in Barca et al. (1995b), new samplings attempted to provide fresh data from the Scivu Is Arenas section, in the Arburese region (Figs. 1C, 4), but they were all unsuccessful. However, thanks to the partial figuration of the aforementioned paper, a taxonomic reinterpretation of this section was attempted (see also the supplementary data). Therefore, a more precise age for the basal marly levels of the carbonate member of the Punta $\mathrm{Su}$ Nuraxi Formation has now been provided. As the authors correctly deduce the presence of Hexasaccites muelleri and Cristianisporites triangulatus, they consider that the association would be from the Pelsonian-Illyrian age (Doubinger \& Bühmann, 1981; Doubinger \& Adloff, 1980; Visscher \& Brugman, 1981; Brugman, 1983; Eshet, 1990; Diez, 2000; Diez et al. 2010), which would be supported by the coexistence with Cyclotriletes oligogranifer and Triadispora suspecta. However, a reinterpretation of the published photos allows us to identify Punctatisporites triassicus and Verrucosisporites thuringiacus, which, on the basis of their last records, would restrict the dating to the Pelsonian (Doubinger \& Bühmann, 1981; Doubinger \& Adloff, 1980) (Fig. 10).

\section{Paleogeographic inferences}

The precise configuration of the Western Tethys during the Middle Triassic, and in particular the position of Sardinia in this domain, has always been subject to debate (e.g., Costamagna \& Barca, 2002). The data presented in this work shed more light on this topic, as the microfloristic associations studied, along with the regional facies correlations, enhance our understanding of the timings of the Western Tethys transgression in the western Mediterranean Triassic domain. This allows us to propose a new hypothesis regarding the paleogeographical evolution of this domain during the Anisian. It has been possible to identify three important steps/stages of evolution:

1) First step (late Pelsonian, Fig. 11a). The northwestern and southeastern part of Sardinia (data from Cugiareddu well, Nurra region and ourcrops in the Sarcidano region) were the first sectors of the island to be affected by the first transgressive pulse, which occurred through the development of small seaways that previously crossed the southern Catalan basin and parts of the eastern Iberian basin (Fig. 12), determining the deposition of the lower Muschelkalk facies or Landete Fm, represented by a shallow marine carbonate platform environment (Escudero-Mozo et al., 2015). During this period, most of the islands of Sardinia and Minorca still constituted 


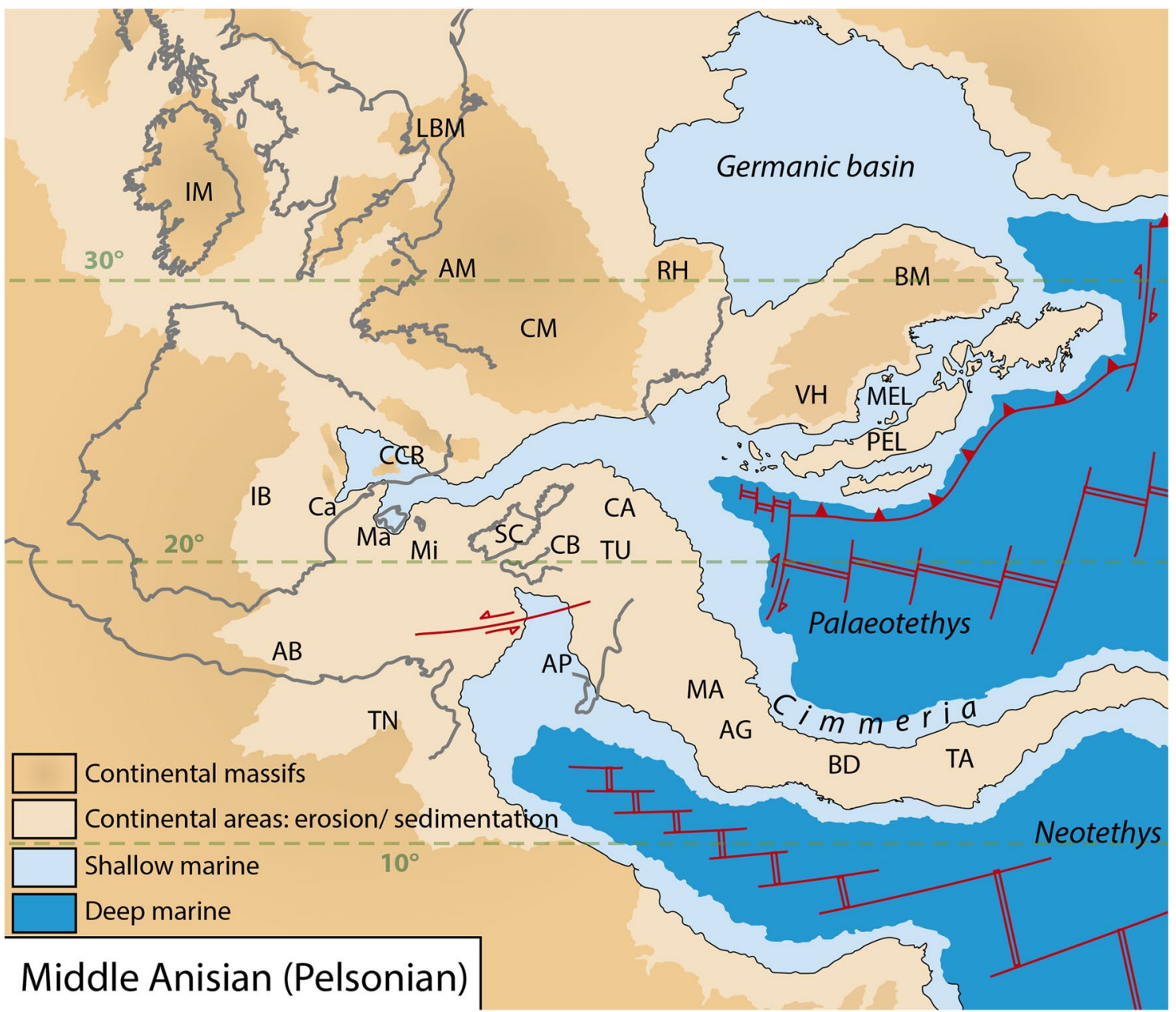

Fig. 12 Paleogeographic reconstruction of the western Tethys realm for the Middle Triassic (middle Anisian). $A M$ Armorica; $A B$ Alboràn; $A G$ Authoctonus Greece; $A P$ Apulia; $B A$ Balearic; $B D$ Bey-Daglari; $B M$ Bohemian Massif; $C A$ Carnic; $C B$ Calabria; $C M$ Central Massif; $I B$ Iberian Massif; IM Irish Massif; $L B M$ London-Brabant Massif; MA Mani; MEL Meliata; PEL Pelagonia; SC Sardinia-Corsica;

high terrestrial areas (Costamagna \& Barca, 2002; Escudero-Mozo et al., 2014) where erosion or continental sedimentation persisted. At this stage, these elevated areas acted as a barrier between the different Tethys realms and still experienced continental sedimentation in the Buntsandstein facies.

2) Second step (early Illyrian, Fig. 11b). As the transgression progressed, during the Pelsonian/Illyrian, there was a gradual evolution to a more transitional marine environment. Following this new sea level rise, related to the northward shift of Cimmeria (Escudero-Mozo et al., $2014,2015)$, more areas were progressively covered by epicontinental seas, including the southernmost sector of Sardinia (Sulcis-Iglesiente region), while Minorca and the northern Catalonian basin (Escudero-Mozo et al.,
$T A$ Taurus; $T N$ Tunisia; $T U$ Tuscan; $R H$ Rhenish Massif; $V H$ Vindelician High; $M i$ Minorca; $M a$ Majorca; $C C B$ Catalan Coastal Basin; $C a$ Castellón. Image modified from Escudero-Mozo et al. (2015) Ziegler and Stampfli (2001), Stampfli and Borel (2002) and Muttoni et al. (2009)

2014, 2015) and the eastern Castellón area (LópezGómez et al., 1998; Escudero-Mozo et al., 2015; Ortí et al., 2020) in eastern Iberia were still represented by continental elevated areas during the middle Illyrian (Fig. 12). This configuration represented an important paleogeographic barrier in the Tethys Sea and it determined the distribution of fauna in northern and southern Cimmeria (Escudero-Mozo et al., 2015).

3) Third step (Fassanian, Fig. 11c). The new transitional pulse that took place during the middle-late Illyrian represented the complete incursion of the Tethys sea in its western domain, including central-eastern Iberia and the Balearic Islands, as well as most of Central and Southern Europe (Gianolla \& Jaquin, 1998; Ziegler, 1999; 
Sanz De Galdeano et al., 2001; Martín-Algarra \& Vera, 2004; Pérez-López \& Pérez-Valera, 2007; Martín-Rojas et al., 2009; Mercedes-Martín et al., 2013; EscuderoMozo et al., 2015; Ortí et al., 2020). Over the course of this step, the evaporitic conditions (sabkha environment) which characterized most of the upper Anisian in Sardinia eventually gave way to a shallow marine environment in the whole island.

\section{Conclusions}

The new stratigraphic analyses and palynological samplings presented in this work, as well as the close review of all the previous palynological publications on the Sardinian Anisian, enhance our framing of the stratigraphical, sedimentological and palynological aspects of the three key Middle Triassic successions of Sardinia: the Su Passu Malu section (Campumari, SW Sardinia), the Arcu is Fronestas section and the Escalaplano SW section (Escalaplano, Central Sardinia). Moreover, the integration of these data with those obtained from other sectors of Sardinia and Western Europe make it possible to evaluate the paleogeographical evolution of the Western Tethys realm during the late Anisian-early Ladinian with greater precision.

The main conclusions can be summarized as follows:

1) The palynostratigraphical associations analyzed provided precise data on the age of the studied sections. It was possible to attribute the Escalaplano Formation to the Pelsonian, thanks to the data obtained from the Escalaplano SW and Arcu is Fronestas sections. As regards the Campumari succession, the sample from Su Pasu Malu Member (Campumari Formation) gave an Illyrian age-constraint. No indications of Early Triassic or lower Anisian associations were identified.

2) These data allow us to define with greater accuracy the Tethys Sea incursion towards its westernmost domains during the Middle Triassic, as well as the different stages of the transgression in Sardinia during the late Anisianearly Ladinian.

3) Sardinia, together with Minorca and the eastern area of Castellón (easternmost Iberia), constituted a topographical high area until the middle-late Illyrian (late Anisian), when an important change in the configuration of the Western Tethys realm occured. Up until that point, the Sardinia-Minorca block had played a key role by acting as a barrier between the realms of the Paleotethys and Neotethys seas.

4) From the late Illyrian to the early Fassanian, the new transgression of the Tethys Sea progressively covered
Sardinia with shallow marine deposits that also reached the neighbouring easternmost Iberia and Minorca areas. During this transgression, almost all the elevated areas of the Western Tethys domain were finally covered by the shallow seas.

Supplementary Information The online version contains supplementary material available at https://doi.org/10.1007/s41513-021-00184-x.

Acknowledgements The authors thank Annalisa Flaviani and Anna Gandin for their kindness and support in providing part of the data. Funds were provided by a University of Pavia $\mathrm{PhD}$ research grant (Lorenzo Stori) and project PGC2018-098272-B-100 (Spanish Ministry of Science, Innovation and Universities). This research is also a contribution to the University Complutense Research Projects: Basin Analysis (910429) and Palaeoclimatology and Global Change (910198). We thank Matthew Clarke for the English revision of the manuscript. The authors thank Alberto Pérez-López, an anonymous reviewer and the associate editor Laura Domingo for their helpful comments on the manuscript.

\section{Declarations}

Conflict of interest On behalf of all the authors, the corresponding author states that there is no conflict of interest.

Open Access This article is licensed under a Creative Commons Attribution 4.0 International License, which permits use, sharing, adaptation, distribution and reproduction in any medium or format, as long as you give appropriate credit to the original author(s) and the source, provide a link to the Creative Commons licence, and indicate if changes were made. The images or other third party material in this article are included in the article's Creative Commons licence, unless indicated otherwise in a credit line to the material. If material is not included in the article's Creative Commons licence and your intended use is not permitted by statutory regulation or exceeds the permitted use, you will need to obtain permission directly from the copyright holder. To view a copy of this licence, visit http://creativecommons.org/licenses/by/4.0/.

\section{References}

Angiolini L., Crippa G., Muttoni G \& Pignatti J., (2013). Guadalupian (Middle Permian) paleobiogeography of the Neotethys Ocean. Gondwana Research 24: 173-184

Antonescu, E., (1969). Deux nouveaux types de spores dans les depots du Trias Moyen des Environs De Cristian (Roumanie). Rev. Micropaleontol. ; Fra; 1969(6), Vol. 12(0001), 9-15.

Barca, S., \& Costamagna, L.G., (2003a). Analisi di facies e stratigrafia della successione permo?-triassica di Campumari-Coremò (Iglesiente, Sardegna SW). Boll. Soc. Geol. It. 122, 25-45

Barca S., Costamagna L.G. \& Del Rio M. (1995a). La successione triassica di Scivu-Is Arenas (Sardegna sud-occidentale). Nuovi dati stratigrafici e sedimentologici. Atti Soc. Tosc. Sci. Nat., Mem Serie A, 102, 5-15

Barca S., Costamagna L.G. \& Del Rio M. (1995b). Affioramenti permo-carboniferi e mesotriassici fra Porto Piscinas e Punta Acqua Durci (Arburese, Sardegna SW) Boll. Soc. Sarda Sci. Nat Sassari, 30, 1-11. 
Barca S. \& Costamagna L.G. (1997b). The Triassic succession of Campumari and Scivu-Is Arenas (SW Sardinia, Italy): analogues, correlations and some remarks. $18^{\circ}$ IAS Meeting, Heidelberg, September 1997, Abstracts Book: 60, Heidelberg.

Barca S., Del Rio M. \& Pittau P., (2004). The Middle Triassic deposits of Escalaplano. In BARCA S. \& Cherchi A. (eds), Sardinian Paleozoic Basement and its Meso- Cainozoic covers, Field Trip Guide Book, XXXII IGC Firenze 2004, APAT.

Borruel-Abadía V., Barrenechea J.F., Galán-Abellán A.B., De La Horra R., López-Gómez J., Ronchi A., Luque F.J., Alonso-Azcárate J \& Marzo M., (2019). Could acidity be the reason behind the Early Triassic biotic crisis on land?, Chemical Geology,515, 77-86, ISSN 0009-2541

Bourquin, S., Bercovici, A., López Gómez, J.B., Diez, J., Broutin, J., Ronchi, A., Durand, M., Arché, A., Linol, B. \& Amour, F. (2011). The Permian-Triassic transition and the onset of Mesozoic sedimentation at the northwestern peri-Tethyan domain scale: Paleogeographic maps and geodynamic implications, Paleogeogr. Paleocl. Paleoecol., 299(1-2), 265-280.

Bourquin S., Durand M., Diez, J.B., Broutin, J. \& Fluteau, F. (2007). The permian-triassic boundary and early Triassic sedimentation in Western European basins: an overview. Journal of Iberian Geology, 33, 221-236.

Broutin, J., Cassinis, G., Cortesogno, L., Gaggero, L., Ronchi, A. \& Sarria, E. (1996). Research in progress on the Permian deposits of Sardinia (Italy). Permophiles, a Newsletter of SPS, 28, 45-48.

Brugman, W.A. (1983). Permian-Triassic palynology state university of Utrecht, The Netherlands 121

Brugman, W.A., (1986). A palynological characterization of the Upper Scythian and Anisian of the Transdanubian Central Range (Hungary) and the vincentinian Alps (Italy). PhD Thesis. Univ. de Utrecht, p. 95

Carrillat A., Martini R., Zaninetti L., Cirilli S., Gandin, A. \& Vrielynck, B. (1999). The Muschelkalk (Middle to Upper Triassic) of the Monte di Santa Giusta (NW Sardinia): sedimentology and biostratigraphy. Eclogae Geologicae Helvetiae, 92, 81-97.

Cassinis, G., Durand, M. \& Ronchi, A., (2003). Permian-Triassic continental sequences of northwest Sardinia and south Provence: stratigraphic correlations and palaeogeographic implications. In: Decandia F.A., Cassinis G. \& Spina A., Eds., Spec. Proc. Int. Meeting «Late Palaeozoic to Early Mesozoic events of Mediterranean Europe, and additional regional reports», Siena, 2001. Boll. Soc. Geol. It. Vol. Spec., 2, 119-129.

Cirilli S., (2010). Upper Triassic-lowermost Jurassic palynology and palynostratigraphy: a review. Geological Society, London, Special Publications, 334, 285-314.

Citton P., Ronchi A., Nicosia U., Sacchi E., Maganuco S., Cipriani A., Innamorati G., Zuccari C., Manucci F. \& Romano M., (2020). Tetrapod tracks from the Middle Triassic of NW Sardinia (Nurra region, Italy), Ital. J. Geosci., 139(2), 309-320. 6 figs. (https:// doi.org/10.3301/IJG.2020.07) @ Società Geologica Italiana, Roma 2020 .

Cocozza, T. ,\& Gandin, A .(1976). Età e significato ambientale delle facies detritico-carbonatiche dell'altopiano di Campumari (Sardegna sud-occidentale). Boll. Soc. Geol. It., 95, 1521-1540

Costamagna, L.G., Barca, S., Del Rio, M. \& Pittau, P. (2000). Stratigrafia, paleogeografia ed analisi di facies deposizionale del Trias del Sarcidano-Gerrei (Sardegna SE). Boll. Soc. Geol. It., 119, 473-496.

Costamagna, L.G. \& Barca, S. (2002). The «Germanic» Triassic of Sardinia (Italy): a stratigraphic, depositional and paleogeographic review. Riv. Ital. Paleont. Strat., 108(1), 67-100.

Costamagna L.G., Barca S. \& Lecca L. (2007). The Bajocian-Kimmeridgian Jurassic sedimentary cycle of eastern Sardinia: stratigraphic, depositional and sequence interpretation of the new «Baunei Group». C.R. Geoscience, 339(9), 601-612.
Costamagna, L. G. (2011). Alluvial, aeolian and tidal deposits in the Lower to Middle Triassic "Buntsandstein" of NW Sardinia (Italy): a new interpretation of the Neo-Tethys transgression. Z. dt. Ges. Geowiss., 163/2, 165-183, 18 figs., 2 tables Article Stuttgart, June 2012.

Costamagna, L.G. (2012). Facies analysis, stratigraphy and petrographic data from the Permian-Middle Triassic Cala Bona-Il Cantaro rock sections (Alghero, NW Sardinia, Italy): contribution to the post-Variscan Nurra basin evolution.

Costamagna, L.G. (2016). Middle Jurassic continental to marine transition in an extensional tectonics context: the Genna Selole Fm depositional system in the Tacchi area (central Sardinia, Italy). Geological Journal, 51, 722-736.

Costamagna, L. G., Barca, S. (2016). The Triassic and Jurassic sedimentary cycles in Central Sardinia: stratigraphy, depositional environment and relationship between tectonics and sedimentation. Geological Field Trips, 8(1.1), 78. https://doi.org/10.3301/ GFT.2016.01.

Costamagna, L. (2019). The carbonates of the post-Variscan basins of Sardinia: The evolution from Carboniferous-Permian humidpersistent to Permian arid-ephemeral lakes in a morphotectonic framework. Geological Magazine, 156(11), 1892-1914. https:// doi.org/10.1017/S0016756819000232.

Damiani, A.V. \& Gandin, A. (1973a). L'affioramento triassico del Monte Maiore di Nureci (Sardegna centrale) Nota i. Boll. Soc. Geol. It., 92, 355-362.

Damiani, A.V. \& Gandin, A. (1973b). Geologia ed ambiente di sedimentazione della successione triassica di M. Maiore (Sardegna centrale). Nota II. Boll. Soc. Geol. It., 92 (Suppl.), 41-83.

Damiani, A.V. \& Gandin, A. (1973c). Il Muschelkalk della Sardegna centro meridionale. Boll. Serv. Geol. It., 94, 81- 116.

Dieni, I., Fischer, J.C., Massari, F., Salard-Cheboldaeff, M. \& Vozenin, S.C. (1983). La succession de Genna Selole (Baunei) dans le cadre de la paléogéographie mésojurassique de la Sardaigne orientale. Mem. Sci. Geol Padova, 36, 117-148.

Diez, J.B., (2000). Geología y Palaeobotánica de la Facies Buntsandstein en la Rama Aragonesa de la Cordillera Ibérica. Implicaciones bioestratigráficas en el Peritethys Occidental. Ph.D. thesis, Universidad de Zaragoza/Université Paris VI.

Diez, J.B., Broutin J. \& Ferrer, J. (2005). Difficulties encountered in defining the Permian-Triassic in Buntsandstein facies of the western Peritethyan based on palynological data. Palaeogeography, Palaeoclimatology, Palaeoecology, 229, 40-53.

Diez, J. B., Broutin, J., Grauvogel-Stamm, L., Bourquin, S., Bercovici, A., \& Ferrer, J. (2010). Anisian floras from the NE Iberian Peninsula and Balearic Islands: A synthesis. Review Of Palaeobotany And Palynology, 162, 522-542.

Dockter J., Puff P., Seidel G. \& Kozur, H. (1980). Zur trias gliederung und symbolgeburg in der D.D.R Zeitschrift Fur Geologische Wissenschaften, 8, 951-963

Dorn, P., (1940). Keuper in germanischer Fazies in Ostsardinien, Zentralbl. Mineral. Geol. Paleontol., Abt. B, Stuttgart.

Doubinger, J. \& Adloff, M.C., (1983). Triassic palynomorphs of the Mediterranean area. C.N.R.S. Rapport Centre de Sédimentologie et Géochimie de la Surface, Strasbourg, France, p. 26

Doubinger, J. \& Bühmann, D. (1981). Röt bei Borken und bei Schlüchtern (Hesse, Deuschland) Palynologie und Tonmineralogie. Z. Dt. Geol. Ges., 132, 421-449

Durand, M. (2006). The problem of the transition from the Permian to the Triassic Series in southeastern France: comparison with other Peritethyan regions. In: Lucas S.G., Cassinis G. \& Schneider J.W. (eds.). Non-Marine Permian Biostratigraphy an Biochronology. Geol. Soc., London, Spec. Publ., 265, 281-296.

Durand, M. (2008). Permian to Triassic continental successions in southern Provence (France): an overview. Bollettino Societa Geologica Italiana, 127, 697-716. 
Escudero-Mozo, M.J., Martín-Chivelet, J., Goy A., López-Gómez, J. (2014). Sedimentary. Geology, 310, 41-58.

Escudero-Mozo M.J., Márquez-Aliaga A., Goy A., Martín-Chivelet J., López-Gómez J., Márquez L., Arche A., Plasencia P., Pla C., Marzoe M. \& Sánchez-Fernández, D. (2015). Middle Triassic carbonate platforms in eastern Iberia: evolution of their fauna and palaeogeographic significance in the western Tethys. Palaeogeography, Palaeoclimatology, Palaeoecology, 417, 236-260

Eshet, Y. (1990). Paleozoic-Mesozoic palynology of Israel. 1. Palynological aspects of the Permo-Triassic sucession in the Subsurface of Israel. Geological Survey of Israel, 81, 1-57.

Fazzini P., Gasperi G.\& Gelmini, R. (1974). Ricerche sul Verrucano. 2. Le successioni basali dei Tacchi tra Escalaplano e Jerzu (Sardegna sud-orientale) Boll. Soc. Geol. It., 93, 221-243

Flaviani, A. (1980). Palinologia e stratigrafia del Trias del sondaggio Cugiareddu: Sardegna nord occidentale. Thesis, unpublished. Cagliari University.

Fontana, D., Gelmini, R. and Lombardi, G. (1982). Le successioni sedimentarie e vulcaniche carbonifere e permo-Triassiche della Sardegna. In Guida alla Geologia del Paleozoico sardo. Guide Geologiche Regionali, Boll. Soc. Geol. It., 183-192.

Fontana D., Neri, C., Ronchi, A. \& Stefani, C. (2001). Stratigraphic architecture and composition of the Permian and Triassic siliciclastic succession of Nurra (north-western Sardinia). In Cassinis G. (Ed.): The Continental Permian of the Southern Alps and Sardinia (Italy). Regional reports and general correlations, 25, 149-161.

Frechengues, M., Peybernes, B., Fournier-Vinas, C. \& Lucas, C. (1993). Palynologic assemblages within the depositional sequences from the middle to Late Triassic series of the spanish and french Pyrenees. Rev. Esp. Paleo. 25(3), 91-105.

Gianolla, P. \& Jaquin, T. (1998). Triassic sequences stratigraphc framework of western European basins. In: DE Graciansky P.C., Hardenbol J., Jaquin T. \& Vail P. (Eds.), Mesozoic and Cenozoic Sequences Stratigraphy of European Basins. Society for Sedimentary Geology, Special Publication 60, 643-650.

Kürschner W. \& Waldemaar Herngreen, G.F., 2010. Triassic palynology of central and northwestern Europe: a review of palynofloral diversity patterns and biostratigraphic sub-divisions, in: LUCAS S.G. (Eds.), Triassic Timescale. Geological Society of London, London, United Kingdom; Special Publications 334, 263-283.

Lovisato, D. (1884). Nota sopra il Permiano ed il Triassico della Nurra in Sardegna. Boll. R. Com. Geol. d'It., 15: 305-324, Roma.

López-Gómez, J., Arche, A., Calvet, F., \& Goy, A. (1998). Epicontinental marine carbonate sediments of the Middle and Upper Triassic in the westernmost part of the Tethys Sea, Iberian Peninsula. Zentralblatt Geologie Paleontologie, 1, 9-10.

Martín-Algarra, A, \& Vera, J.A., (2004) La Cordillera Bética y las Baleares en el contexto del Mediterráneo POccidental. In: Vera, J.A. (Ed.), Geología de España. Sociedad Geológica de España. Instituto Geológico y Minero de España, Madrid, 352-354.

Martín-Rojas, I., Somma, R., Delgado, F., Estévez, A., Iannace, A. \& Perrone, V. (2009). Triassic continental rifting of Pangaea: direct evidence from the Alpujarride carbonates, Betic Cordillera, SE Spain. Journal of Geological Society, London, 166, 447-458.

Mercedes-Martín, R., Salas, R. \& Arenas, C. (2013). Microbial-dominated carbonate platforms during the Ladinian rifting: sequence stratigraphy and evolution of accommodation in a fault-controlled setting (Catalan Coastal Ranges, NE Spain). Basin Research, 25, $1-28$.

Mietto, P., Manfrin, S., Preto, N., Rigo, M., Roghi, G., Furin, S., Gianolla, P., Posenato, R., Muttoni, G., Nicora, A., Buratti, N., Cirilli, S., Spötl, C., Ramezani, J. \& Bowring, S.A. (2012) The global boundary stratotype section and point (GSSP) of the Carnian stage (Late Triassic) at Prati di stuores/stuores Wiesen section (Southern Alps, NE Italy). Episodes, 35,(3), 414-420.
Muttoni, G., Gaetani, M., Kent, D.V., Sciunnach, D., Angiolini, L., Berra, F., Garzanti, E., Mattei, M. and Zanchi, A. (2009). Opening of the Neo-Tethys Ocean and the Pangea B to Pangea A transformation during the Permian. GeoArabia, v. 14, no. 4, 2009, p. 17-48 Neo-Tethys opening and Pangea transformation. Gulf PetroLink, Bahrain.

Moore, R.C. (1962) Treatise of Invertebrate Paleontology, Vol. W, Miscellanea. Geol. Soc. America, University of Kansas Press, Boulder, Colorado, and Lawrence, Kansas.

Novarese, V. (1914) Il rilevamento geologico delle tavolette Iglesias e Nebida. Boll. R. Com. Geol. Italiano, 44, 29-59, Roma.

Ortí, F., Guimerà, J., \& Götz, A. E. (2020). Middle-Upper Triassic stratigraphy and structure of the Alt Palància (eastern Iberian Chain): A multidisciplinary approach. Geologica Acta, 18(4), 1-25. https://doi.org/10.1344/GeologicaActa2020.18.4.

Pastor-Galán, D., Groenewegen, T., Brouwer, D., Krijgsman, W. \& Dekkers, M.J. (2015). One or two oroclines in the Variscan orogen of Iberia ? Implications for Pangea amalgamation Geology, 43: $527-530$

Payne, J.L. \& Kump, L.R. (2007). Evidence for recurrent Early Triassic massive volcanism from quantitative interpretation of carbon isotope fluctuations. Earth and Planetary Science Letters, 256, 264-277.

Pecorini, G. (1974). Nuove osservazioni sul Permo-Trias di Escalaplano (Sardegna sud-orientale). Boll. Soc. Geol. It., 93, 991-999

Pérez-López, A. \& Pérez-Valera, F. (2007) Palaeogeography, facies and nomenclature of the Triassic units in the different domains of the Betic Cordillera (SE Spain). Palaeogeography, Palaeoclimatology, Palaeoecology, 254, 606-626.

Pertusati, P.C., Sarria, E., Cherchi, G.P., Carmignani, L., Barca, S., Benedetti, M., Chighine, G., Cincotti, F., Oggiano, G., Ulzega, A., Orru, P. \& Pintus, C. (2002a). Note illustrative della Carta Geologica d'Italia alla scala 1:50.000-Foglio 541 Jerzu. Servizio Geologico Nazionale-Regione Autonoma Sardegna, p. 168

Pertusati, P.C., Sarria, E., Cherchi, G.P., Carmignani, L., Barca, S., Benedetti, M., Chighine, G., Cincotti, F., Oggiano, G., Ulzega, A., Orru, P. \& Pintus, C. (2002b). Foglio 541 Jerzu-Carta Geologica d'Italia alla scala 1:50.000. Servizio Geologico Nazionale. Regione Autonoma Sardegna.

Pittau Demelia, P. \& Del Rio, M. (1980). Pollini e spore del Trias medio e del Trias superiore negli affioramenti di Campumari e di Ghisciera Mala (Sardegna). Boll. Soc. Paleont. It., 19, 241-249, Modena.

Pittau Demelia, P. and Flaviani, A. (1982a). Palinostratigrafia della serie Triassica di Punta del Lavatoio (Sardegna nord-occidentale). Riv. It. Paleont. Strat., 88, 401-416, Milano.

Pittau Demelia, P. and Flaviani, A. (1982b). Aspect of the palynostratigraphy of the Triassic Sardinia sequences (Preliminary report). Rev. Palaeobot. and Palyn. 37, 377-380, Amsterdam.

Pittau, P. \& Rio Del, M. (2002). Palynofloral biostratigraphy of the Permian and Triassic sequences of Sardinia. Rend. Soc. Paleont. It. 1, 93-109.

Pittau, P., Del Rio M. \& Funedda, A. (2008). Plant communities characterization and basin formation in the Carboniferous-Permian of Sardinia. Boll. Soc. Geol. It. (Ital.J.Geosci.), 127(3), 637-653.

Pomesano, C.A. (1968). Studio biostratigrafico del sondaggio Cugiareddu nel Trias e Permico della Nurra nord-occ Univ 61.

Posenato, R., Simone, L., Urlichs, M. \& Ibba, A. (2002) The Ladinian Muschelkalk of Punta del Lavatoio (Alghero, NW Sardinia). Rend. Soc. Paleont. Ital., 1, 283-291

Ronchi, A. (1997). I prodotti sedimentari e vulcanici dei bacini permiani di Escalaplano e Perdasdefogu nella Sardegna sudorientale: stratigrafia e loro inquadramento nell'evoluzione tardo-paleozoica del settore sudeuropeo. PhD Thesis, Univ. Parma, p. 231. 
Ronchi, A., Sarria, E. \& Broutin, J. (2008) The «Autuniano Sardo»: basic features for a correlation through the Western Mediterranean and Paleoeurope. Boll. Soc. Geol. It., 127(3), 655-681

Sanz De Galdeano, C., Andreo, B., García-Tortosa, F.J. \& LópezGarrido, A.C. (2001). The Triassic palaeogeographic transition between the Alpujárride and Malaguide complexes, Betic Rift Internal Zone (S Spain, N Marocco). Palaeogeography, Palaeoclimatology, Palaeoecology. 167, 157-173.

Scotese, C.R., Schettino, A., (2017). Late Permian-Early jurassic paleogeography of western Tethys and the world, Permo-Triassic salt provinces of Europe, North Africa and the Atlantic margins, 57-95.

Seilacher, A. (1982). Distinctive features of sandy tempestites G Einsele A Seilacher Eds Cyclic and event stratification, Springer, 333-349.

Sinisi, R., Mongelli, G., Mameli, P., Oggiano, G., (2014). Did the Variscan relief influence the Permian climate of mesoeurope? Insights from geochemical and mineralogical proxies from Sardinia (Italy). Palaeogeogr. Palaeoclimatol. Palaeoecol., 396.

Stampfli, G.M., \& Borel. G.D (2002) A plate tectonic model for the Paleozoic and Mesozoic constrained by dynamic plate boundaries and restored synthetic oceanic isochrones. Earth and Planetary Science Letters, 196, 17-33.

Stampfli, G.M., Hochard, C., Vérard, C., Wilhem, C. \& Raumer Von, J. (2013). The formation of Pangea. Tectonophysics, 593, 1-19.

Sun Y.D., Joachimski M.M., Wignall Ch Chunbo P.B., Haishui J., Lina W. \& Xulo, L. (2012). Lethally hot temperatures during the Early Triassic greenhouse, Science, 338, 366-370
Svensen, H., Planke, S., Polozov, A.G., Schmidbauer, N., Corfu, F., Podladchikov, Y.Y. \& Jamtveit, B. (2009). Siberian gas venting and the end-Permian environmental crisis. Earth and Planetary Science Letters. 277, 490-500.

Taricco, M. (1928). Il Cambriano del Sulcis (Sardegna). Res. Ass. Min. Sarda, 33, 10-29, Iglesias.

Tornquist. A. (1902). Die Gliederung und Fossilifuhrung der ausserlpinen Trias auf Sardinien. Sitz. K. Preuss, Akad. Wiss., 38, 1098-1 1 17, Berlin.

Van Der Eem, J.G.L.A., (1983). Aspects of middle and late triassic palynology. 6. Palynological investigations in the Ladinian and lower Karnian of the Western Dolomites, Italy. Review of Palaeobotany and Palynology, 39(3-4), 189-300.

Visscher, H. \& Brugman, W.A (1981). Ranges of selected palynomorphs in the Alpine Triassic of Europe. Review of Palaeobotany and Palynology, 34, (1), 115-128.

Wignall, P.B (2007). The End-Permian mass extinction-How bad did it get? Geobiology, 5, 303-309.

Wood, G.D., Gabriel, A.M., \& Lawson, J.C. (1996). Palynological techniques—processing and microscopy. In: Jansonius J. \& Mcgregor D.C. (eds.) Palynology: principles and applications, American Association of Stratigraphic Palynologists Foundation, 1, 29-50.

Ziegler, P.A. (1999). Evolution of the Artic-North Atlantic and the Western Tethys AAPG. Bulletin, 43, 164-196.

Ziegler, P.A. \& Stampfli, G.M. (2001). Late Paleozoic-EarlyMesozoic plate boundary reorganization: collapse of the Variscan orogen and opening of Neotethys Natura Bresciana. Ann. Mus. Civ. Sc. Nat. Bresci, 25, 17-34. 